\title{
Assessment of Release Rates for Radionuclides in Activated Concrete
}

\author{
T.M. Sullivan
}

August 21, 2003

Brookhaven National Laboratory

Upton, New York 11973-5000 



\title{
Assessment of Release Rates for Radionuclides in Activated Concrete
}

\author{
T.M. Sullivan
}

August 21, 2003

\author{
Environmental Research and Technology Division \\ Environmental Sciences Department
Brookhaven National Laboratory
P.O. Box 5000
Upton, NY 11973-5000
www.bnl.gov
Managed by \\ Brookhaven Science Associates, LLC \\ for the United States Department of Energy under \\ Contract No. DE-AC02-98CH10886
}

*This work was performed under the auspices of the U.S. Department of Energy 


\section{DISCLAIMER}

This report was prepared as an account of work sponsored by an agency of the United States Government. Neither the United States Government nor any agency thereof, nor any of their employees, nor any of their contractors, subcontractors or their employees, make any warranty, express or implied, or assumes any legal liability or responsibility for the accuracy, completeness, or any third party's use or the results of such use of any information, apparatus, product, or process disclosed, or represents that its use would not infringe privately owned rights. Reference herein to any specific commercial product, process, or service by trade name, trademark, manufacturer, or otherwise, does not necessarily constitute or imply its endorsement, recommendation, or favoring by the United States Government or any agency thereof or its contractors or subcontractors. The views and opinions of author's expresses herein do not necessarily state to reflect those of the United States Government or any agency thereof. 


\section{Table of Contents}

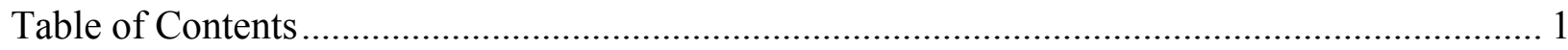

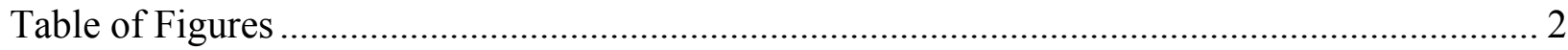

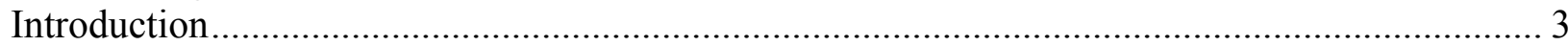

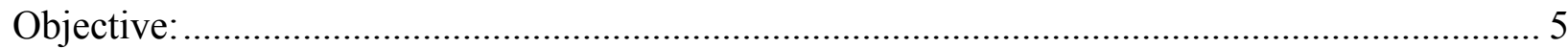

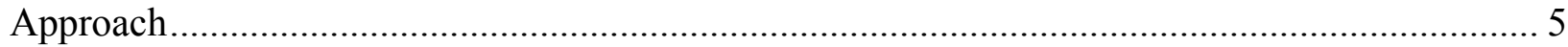

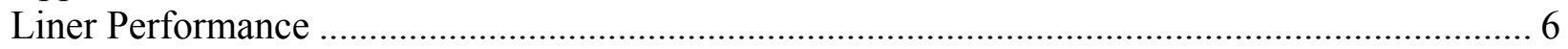

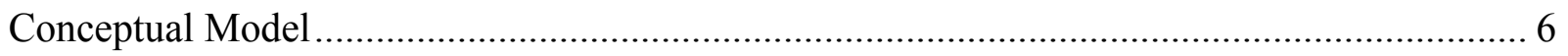

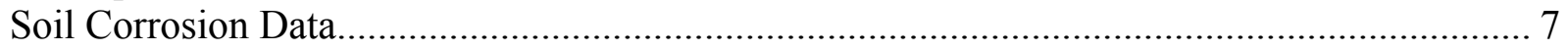

Soil Corrosion Models and Results..................................................................................... 7

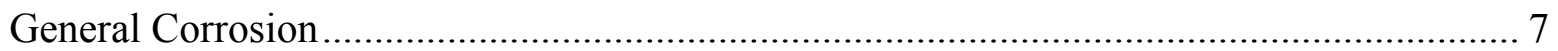

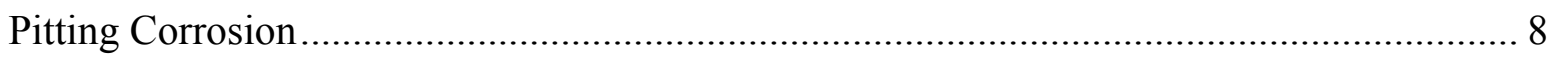

Pitting Corrosion Modeling Results.................................................................................. 10

Selection of Container Lifetimes for Release Analysis ........................................................ 13

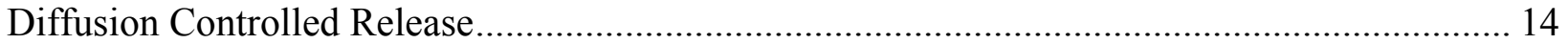

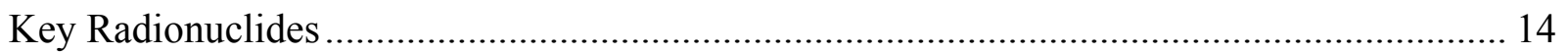

Experimental Diffusion Coefficients ....................................................................................... 15

Predicted H-3 and C-14 Release Rates and Cumulative Release …………............................... 15

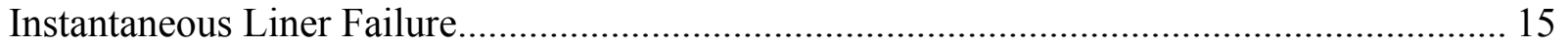

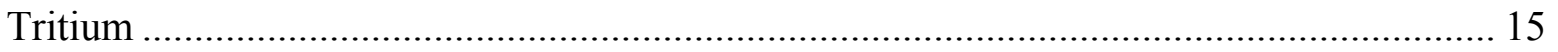

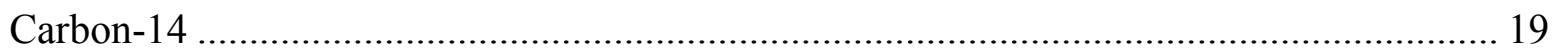

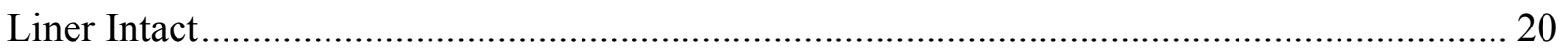

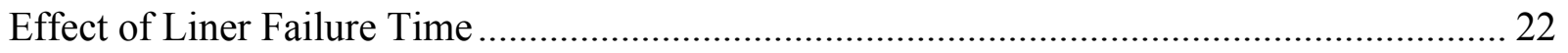

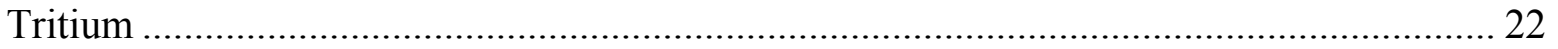

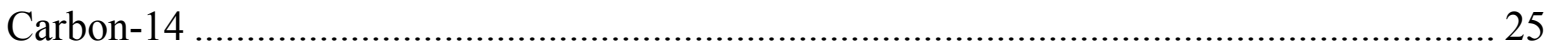

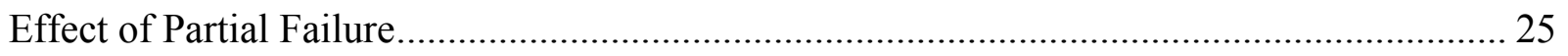

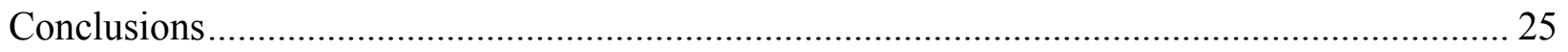

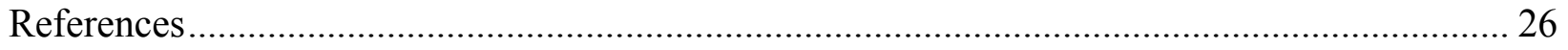




\section{Table of Figures}

Figure 1 Top view of ICI Pit....................................................................................... 3

Figure 2 Cross Section A-A of the ICI sump. Carbon steel liner is outlined in red. ................... 4

Figure 3 Cross Section B-B. Carbon steel liner is outlined in red........................................... 4

Figure 4 Normalized inventory based on coring data. Note, after 30 inches the normalized

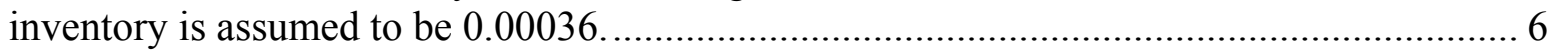

Figure 5 Predicted maximum pit depths as a function of aeration ........................................ 11

Figure 6 fractional areas penetrated by pits as a function of pit density for very poor and fair

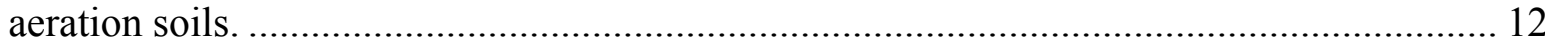

Figure 7 Predicted fractional area penetrated by pitting as a function of $\mathrm{pH}$......................... 13

Figure 8 Schematic diagram of the one-dimensional model used to simulate release from the waste form.

Figure 9 Cumulative fractional release for H-3 in the case of no liner and three values for the diffusion coefficient.

Figure 10 Annual release rates over time in the case of no liner and three values for the diffusion

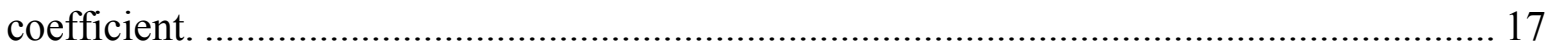

Figure 11 Cumulative fractional amount in solution....................................................... 18

Figure 12 Cumulative fractional release for C-14 in the absence of a liner. ............................ 19

Figure 13 Annual fractional release rate predicted for $\mathrm{C}-14$.................................................. 20

Figure 14 Predicted redistribution of tritium with liner intact and $\mathrm{D}=10^{-6} \mathrm{~cm}^{2} / \mathrm{s} \ldots \ldots \ldots \ldots \ldots \ldots . . \ldots 21$

Figure 15 Predicted redistribution of tritium with liner intact and $\mathrm{D}=10^{-8} \mathrm{~cm}^{2} / \mathrm{s} \ldots \ldots \ldots \ldots \ldots \ldots . . \ldots 22$

Figure 16 Cumulative fractional releases for $\mathrm{H}-3$ for a 25 -year lifetime liner.

Figure 17 Annual Fractional Release for H-3 for a 25-year liner lifetime. ............................. 23 


\section{Introduction}

The Maine Yankee (MY) nuclear power plant is undergoing the process of decontamination and decommissioning (D\&D). Part of the process requires analyses that demonstrate that any radioactivity that remains after D\&D will not cause exposure to radioactive contaminants to exceed acceptable limits. This requires knowledge of the distribution of radionuclides in the remaining material and their potential release mechanisms from the material to the contacting groundwater.

In this study the concern involves radionuclide contamination in activated concrete in the ICI Sump below the containment building. Figures $1-3$ are schematic representations of the ICI Sump. Figure 2 and 3 contain the relevant dimensions needed for the analysis. The key features of Figures 2 and 3 are the 3/8-inch carbon steel liner that isolates the activated concrete from the pit and the concrete wall, which is between 7 feet and 7 feet 2 inches thick. During operations, a small neutron flux from the reactor activated the carbon steel liner and the concrete outside the liner. Current MY plans call for filling the ICI sump with compacted sand.

\section{ICl Pit Activated Concrete}

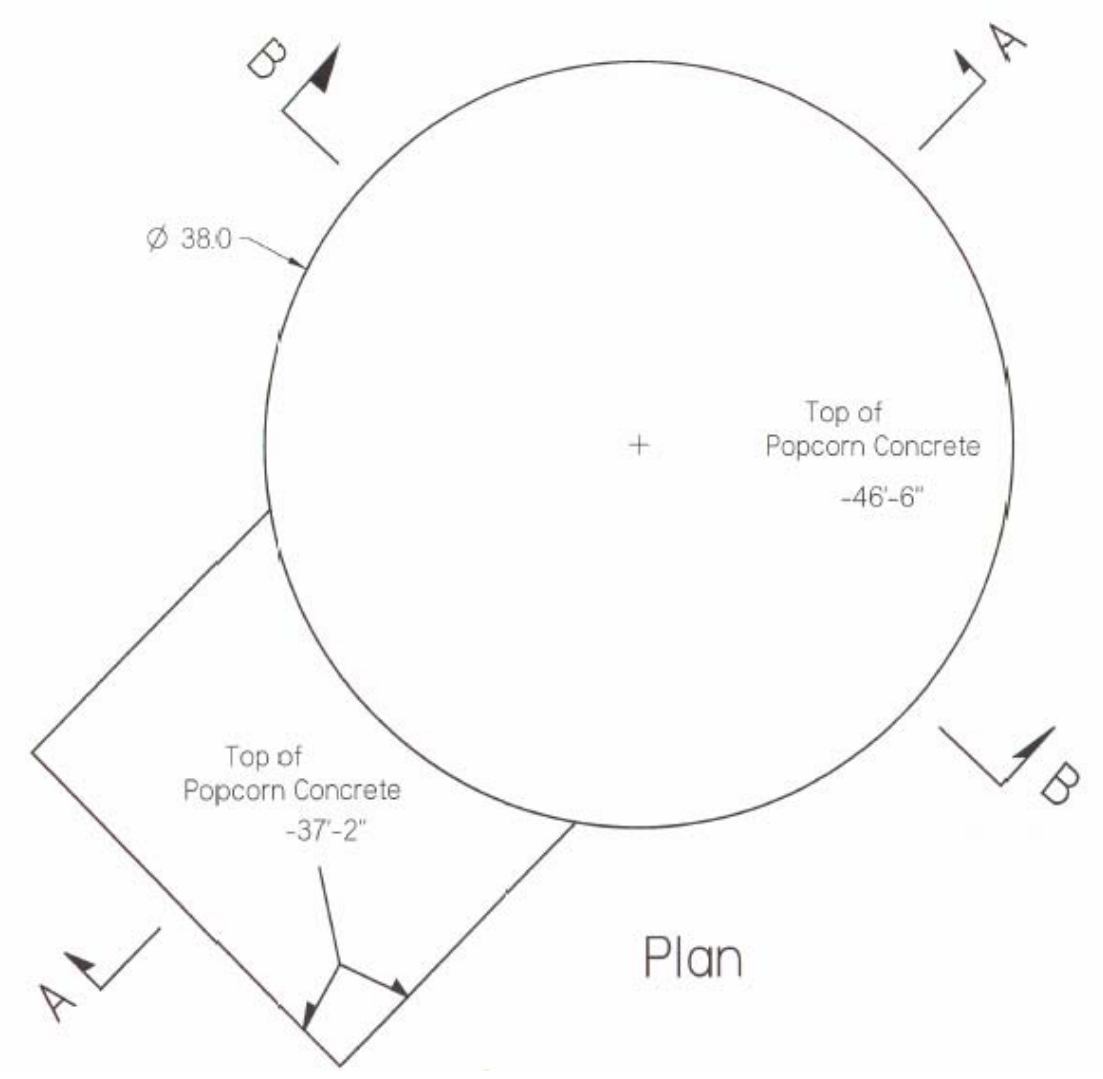

Figure 1 Top view of ICI Pit. 


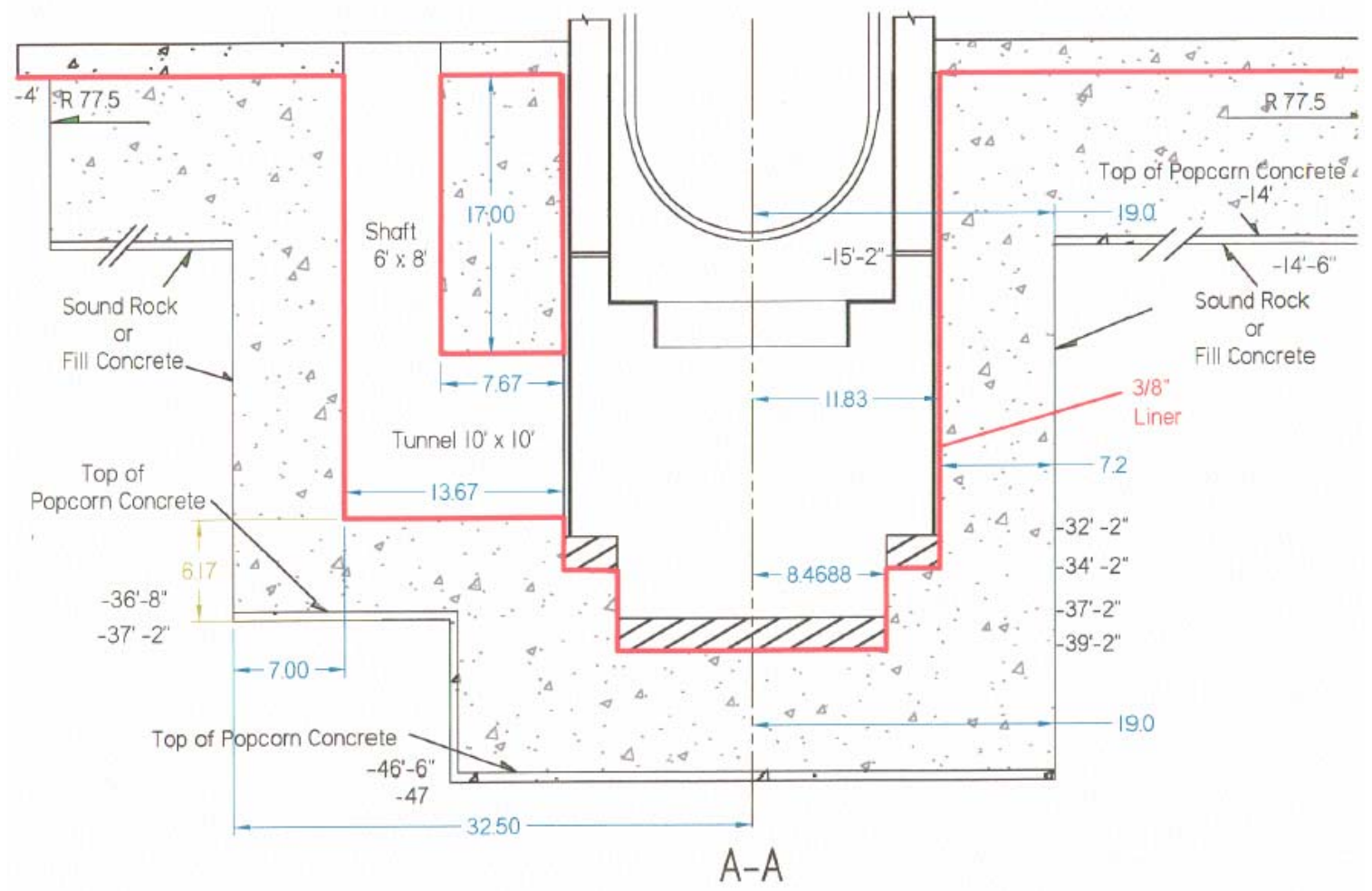

Figure 2 Cross Section A-A of the ICI sump. Carbon steel liner is outlined in red.

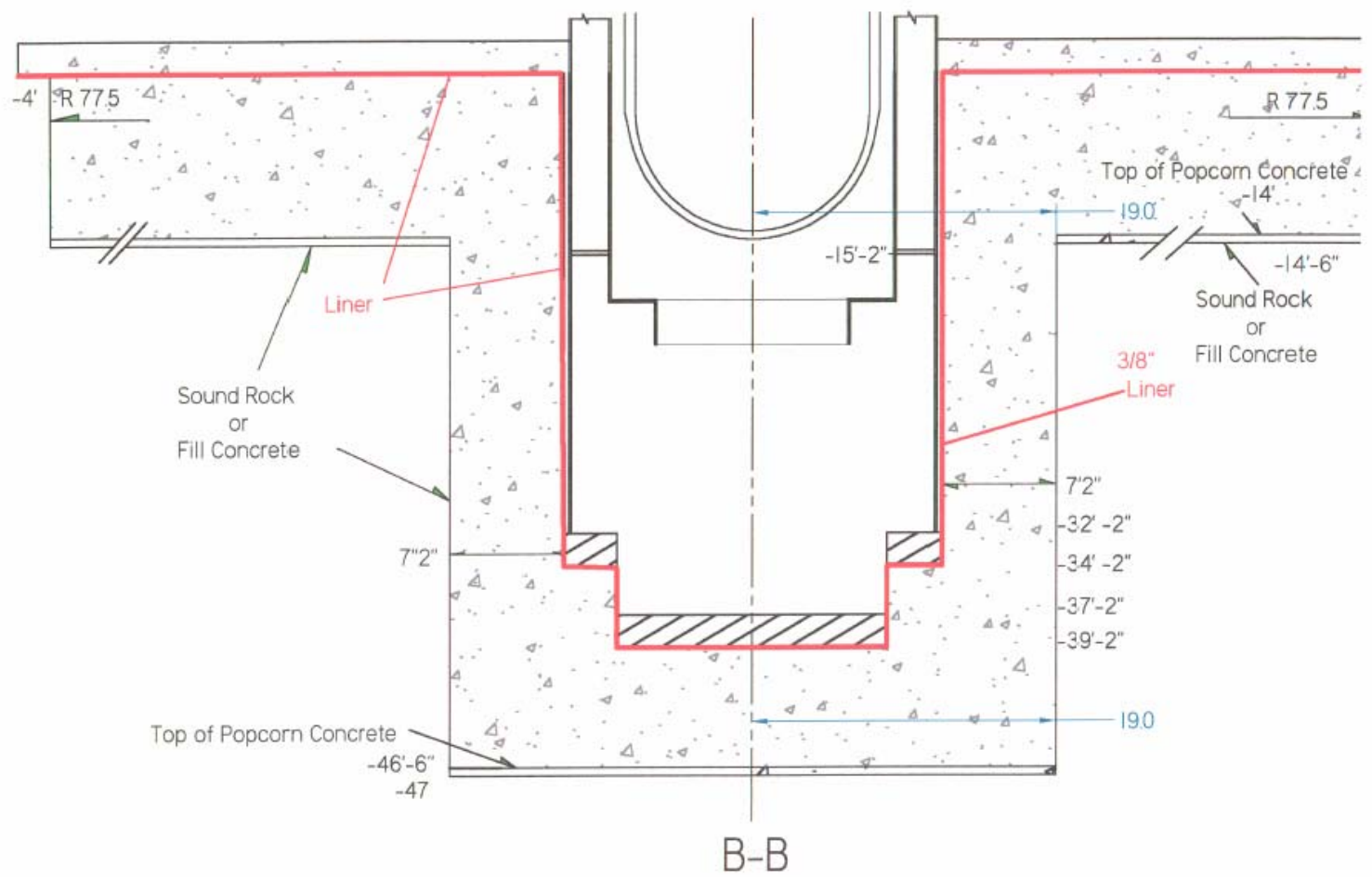

Figure 3 Cross Section B-B. Carbon steel liner is outlined in red. 
Isotope specific characterization data was obtained to define the contamination. Table 1 provides the expected nuclide fractions decayed to January 2004. Characterization included taking approximately $1 \frac{1}{2}$ inch slices of the concrete core. A total of 108 slices were analyzed covering approximately 54 inches. Each slice was analyzed to provide an estimate of the average concentration within the slice. The data indicated a peak in activity at a depth of approximately 2 inches into the concrete. The depth profile found in this characterization study and used in these analyses is presented in Figure 4. Concentrations were normalized to the peak concentration and results are presented in terms of a fractional release of the total inventory. In the data set used for analysis, the concentration of gamma emitting radionuclides was measured and the peak concentration was $2750 \mathrm{pCi} / \mathrm{g}$. This core was taken from a region that will be removed as part of the decontamination effort, but it is the highest activity region of the ICI sump region. A default value of $1 \mathrm{pCi} / \mathrm{g}$ was used for all locations more than 30 inches from the inside wall of the core. This concentration is $3.6 \times 10^{-4}$ of the peak concentration.

Table 1 Nuclide fraction in activated concrete and rebar (Table 2-9 from License Termination Plan)

\begin{tabular}{|c|c|c|}
\hline Nuclide & Fraction in Activated Concrete & Fraction in Activated Rebar \\
\hline H-3 & 0.647 & ------ \\
\hline C-14 & 0.058 & ----- \\
\hline Fe-55 & 0.124 & 0.910 \\
\hline Ni-63 & 0.007 & 0.006 \\
\hline Co-60 & 0.040 & 0.084 \\
\hline Cs-134 & 0.0084 & ------- \\
\hline Eu-152 & 0.111 & ------ \\
\hline Eu-154 & 0.009 & ------- \\
\hline
\end{tabular}

\section{Objective:}

The objective is to determine the normalized release rates and cumulative release of key radionuclides from the activated concrete to the groundwater in the surrounding porous medium as a function of liner performance.

\section{Approach}

Releases will be examined under the following conditions
a) Liner intact
b) Liner failed instantaneously (total failure, equivalent to liner removal)
c) Liner failed at a range of times suggested by liner lifetime estimates.
d) Partial failure of the liner.

A range of liner lifetime estimates will be made based on two failure mechanisms; general corrosion and pitting corrosion. These estimates will be used as the basis of determining releases as a function of liner performance. 
Inventory between surface and depth

Normalized to Peak Concentration

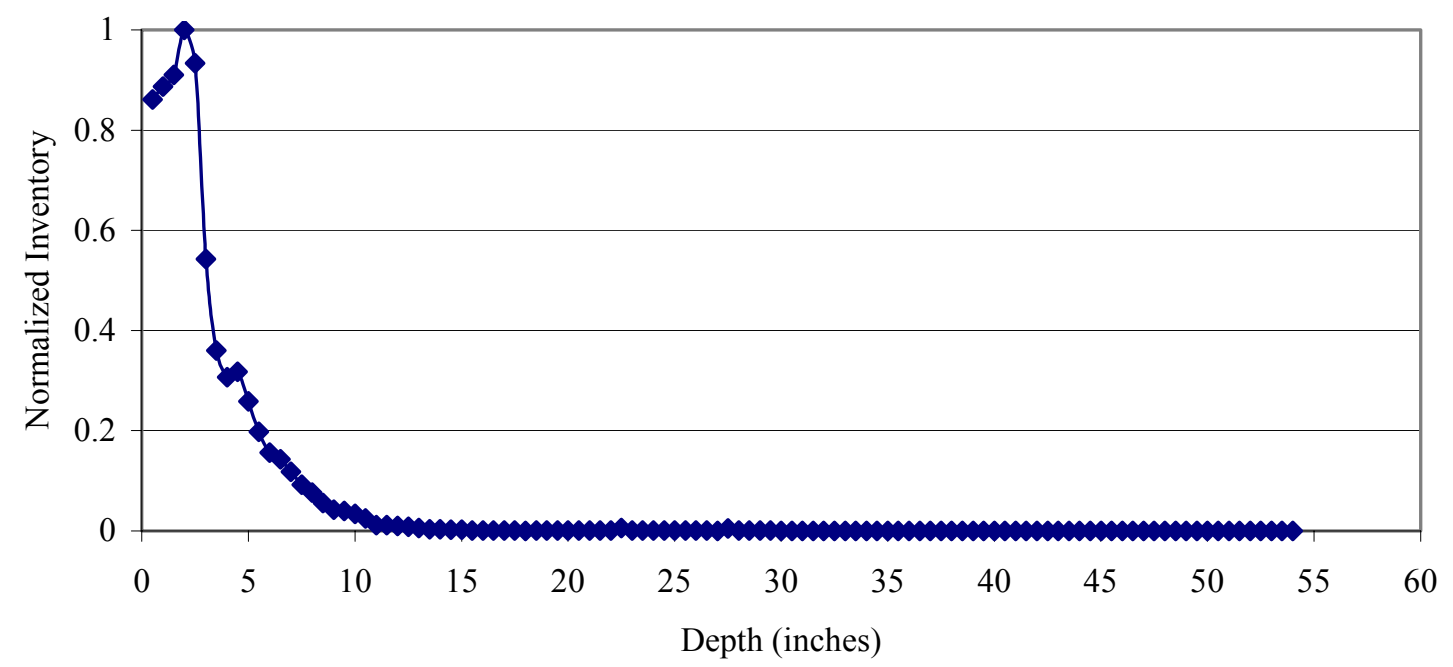

Figure 4 Normalized inventory based on coring data. Note, after 30 inches the normalized inventory is assumed to be 0.00036 .

Key radionuclides will be identified from the inventory data and unit dose conversion factors for activated concrete found in Table 6-5 of the LTP.

The release mechanism from the concrete will be assumed to be diffusion controlled. A number of experimental studies have observed this behavior in concrete for many radionuclides.

Advection is another possible transport mechanism. However, it is not being accounted for because flow would occur through the more permeable host rock if a pressure gradient formed. In addition, while the liner is intact, flow would not occur through the concrete. As the liner failed, transport of the advection front through the 7 feet of concrete would take longer than the diffusion controlled release from the high concentration zone within the first few inches of the liner.

\section{Liner Performance}

\section{Conceptual Model}

The liner is 3/8-inch carbon steel. The exterior of the liner (contacting concrete) is coated with bituminous material or Monel. The interior of the liner is coated with 3-mil thick zinc-silicate based paint, which provides galvanic protection to the liner. Modeling of corrosion will not take credit for the coatings. Two corrosion mechanisms, general corrosion and pitting corrosion will be modeled to estimate lifetime. 


\section{Soil Corrosion Data}

The National Bureau of Standards (NBS, currently National Institute of Standards and Technology) conducted extensive soil corrosion tests (Romanoff, 1957, Gerhold, 1981). Soil coupons were buried and periodically examined for general and pitting corrosion. In total, 333 different materials were tested for periods of up to 18 years in at least one of 128 different soils. The soil properties covered the following range of conditions: resistivity $(64-45,000$ ohm-cm); $\mathrm{pH}$ values $(3.1-9.8)$; residual moisture content $(2.8-585)$; air filled porosity $(1.1-$ $57.8 \%$ ); and aeration properties (very poor to good). In these studies, carbon steel and ferrous metals were exposed to 47 different soils for time periods of up to 14 years. Analysis of the data (Romanoff, 1968) showed that corrosion rates for carbon steel, wrought iron, and ductile iron were similar in these soils. These data form the basis of the analysis of container lifetime.

An important parameter for correlating localized corrosion is the degree of aeration. Aeration provides a measure of the degree of oxygen and moisture that can access the soils. General guidelines for determining aeration can be found in Romanoff [Romanoff, 1957]. Aeration characteristics of a soil are dependent on the physical characteristics such as particle size, particle-size distribution, and apparent specific gravity. All of these are related to the size and continuity of the pore space, which is also related to drainage. Aeration is a more general concept than drainage, however, as aeration also depends on topographic features, depth to the water table, and amount of rainfall. In general, soils of coarse texture, such as sands, tend to have low water-holding capacity and are characterized by high aeration. Fine textured soils, such as clays, tend to have poor aeration. Four aeration categories were defined in the NBS study: good, fair, poor, and very poor. Very poor aerated soils have low resistivity and are known to be corrosive to carbon steel and favor pit growth.

\section{Soil Corrosion Models and Results}

\section{General Corrosion}

The general degradation model assumes that the degradation process is constant and independent of time. For corrosion of metals, this can be conservative because the corrosion data in soil systems generally indicate a decreasing rate of corrosion in time [Romanoff, 1957; Gerhold, 1981]. The output of the general degradation model is the time at which failure occurs, $t_{f}$, and can be determined from the following:

where

$$
\mathrm{t}_{\mathrm{f}}=\mathrm{d} / \mathrm{g}
$$

$\begin{array}{lll}\mathrm{d} & = & \text { degradation allowance thickness }(\mathrm{cm}) \text { and } \\ \mathrm{g} & = & \text { is the general degradation rate }(\mathrm{cm} / \mathrm{yr})\end{array}$

The degradation thickness is the thickness of the container that is allowed to degrade prior to failure. It is often the container thickness minus a fraction of the thickness to account for mechanical failure when the container gets too thin to support the overburden or to account for localized corrosion. 
Table 2 presents the average and range of corrosion rates and lifetimes for a 3/8-inch $(0.95 \mathrm{~cm})$ thick carbon steel liner. Adjustments for localized corrosion or mechanical failure have not been accounted for in Table 2, however, they will be addressed in estimating liner lifetimes for modeling diffusion release.

Table 2 Average and range of corrosion rates and lifetimes for $3 / 8$ inch $(0.95 \mathrm{~cm})$ carbon steel liner

\begin{tabular}{lcc}
\hline & Average $(\mathrm{cm} / \mathrm{s})$ & $\underline{\text { Range }(\mathrm{cm} / \mathrm{s})}$ \\
\hline Rate & $5.710^{-3}$ & $8.510^{-4}-1.910^{-2}$ \\
\hline & Average (years) & Range (years) \\
\hline Lifetime & 168 & $50-1120$
\end{tabular}

Values at the low end of the lifetime range are typically found in poorly aerated soils with either low $\mathrm{pH}$ or high chlorine content. For example, the corrosion rate of carbon steel in a Tidal Marsh setting with a chlorine content of $43 \mathrm{mg} / 100 \mathrm{~g}$ of soil was $1.3 \times 10^{-2} \mathrm{~cm} / \mathrm{yr}$ (Romanoff, 1957). The aeration conditions at Maine Yankee are expected to be fair to good and the chlorine content is expected to be less than $50 \mathrm{ppm}$, therefore, the low end of container lifetime estimates are probably not appropriate.

Independently, Maine Yankee staff estimated a lifetime of 490 years for the 3/8-inch liner in sandy soils in the $\mathrm{pH}$ range of $6-9$. In addition, they estimated a lifetime of 57.8 years for the 3-mil thick zinc-silicate based paint that provides galvanic protection of the carbon steel.

\section{$\underline{\text { Pitting Corrosion }}$}

The objective of the local degradation model is to calculate the fraction of the liner that has been penetrated due to degradation as a function of time. The localized failure model generally permits water access to the activated concrete at earlier times than the general corrosion model. Therefore, it will tend to be more important for short-lived radionuclides that undergo substantial decay prior to release.

The localized failure model is structured to evaluate pitting corrosion of metallic containers. The database used to generate the empirical parameters is based on carbon steel data. The localized corrosion pitting model assumes that a hemispherical pit is formed and estimates the area breached based on the maximum pit depth $\mathrm{h}$, corrosion allowance, $\mathrm{d}$, and the number of penetrating pits per container, $\mathrm{N}_{\mathrm{p}}$. The area breached is equal to

$$
\begin{gathered}
A_{b}=N_{p} \pi\left(h^{2}-d^{2}\right) \\
A_{b}=0 \quad \text { when } h<d
\end{gathered}
$$


$\mathrm{d}$ is the corrosion allowance used for estimating failure time. In these calculations, it is assumed that the corrosion allowance is the entire thickness of the liner. To address concerns about a combination of general and pitting corrosion leading to failure, the failure time used in estimating release will be reduced from the values calculated independently for either mechanism.

The typical distribution of pit sizes shows a large number of small pits with a few deep pits. Marsh conducted pitting experiments for 10,000 hours on carbon steel at $90 \mathrm{C}$ with the contacting solution having $1000 \mathrm{ppm} \mathrm{Cl}^{-}$[Marsh, 1985]. He found a pit density of 8 per square centimeter with a pit depth of at least $0.1 \mathrm{~cm}$. The pit density for large pits was approximately $0.05\left(\mathrm{~cm}^{2}\right)^{-1}$. The large pits represent the pits that will eventually penetrate the container. Based on these data, the number of penetrating pits on carbon steel has been estimated to range between 0.05 and 0.5 per $\mathrm{cm}^{2}$. [Sullivan, 1988]

The maximum pit depth, $h$, is obtained from the data generated by the National Institute of Standards and Technology [Romanoff, 1957] and takes the form:

$$
\mathrm{h}=\mathrm{kt}^{\mathrm{n}}(\mathrm{A} / 372)^{\mathrm{a}}
$$

where

$\begin{array}{lll}\mathrm{k} & = & \text { empirical pitting parameter } \mathrm{cm} / \mathrm{yr}^{\mathrm{n}} \\ \mathrm{t} & = & \text { corrosion time in years, } \\ \mathrm{n} & = & \text { empirical pitting exponent } \\ \mathrm{A} & = & \text { representative surface area in } \mathrm{cm}^{2} \\ \mathrm{a} & = & \text { experimentally derived empirical correlation coefficient. }\end{array}$

The term $(\mathrm{A} / 372)^{\mathrm{a}}$ is correction term to account for the fact that pitting is a statistical process and therefore, the larger area studied, the higher probability of finding a deeper pit. The constant 372 $\mathrm{cm}^{2}$ is a scaling factor and represents the size of the samples in Romanoff's study. The equation above provides an estimate of the maximum pit depth over the entire surface area under evaluation.

Values for the pitting parameter $\mathrm{k}$ and $\mathrm{n}$ were determined as a function of soil aeration and are presented in Table 3 [Mughabghab, 1989]. In the data from Romanoff, the range of values for $\mathrm{k}$ was $0.03-0.15$ with an average value of 0.074 and the range of values for $\mathrm{n}$ was $0-$ 0.92 with an average value of 0.39 .

Table 3 Values for pitting parameters as a function of soil aeration.

\begin{tabular}{|l|c|c|c|c|}
\hline Degree of aeration & Good & Fair & Poor & Very Poor \\
\hline $\begin{array}{l}\text { Pitting Parameter } \\
\mathrm{k}\left(\mathrm{cm} / \mathrm{yr}^{\mathrm{n}}\right)\end{array}$ & 0.094 & 0.086 & 0.052 & 0.068 \\
\hline $\begin{array}{l}\text { Pitting exponent } \\
\mathrm{n}\end{array}$ & 0.26 & 0.39 & 0.44 & 0.59 \\
\hline
\end{tabular}


In addition to estimating the value of the pitting parameter $\mathrm{k}$ as a function of soil aeration, correlations of $\mathrm{k}$ with $\mathrm{pH}$ were obtained (Mughabghab, 1989).

$$
\begin{array}{rr}
\mathrm{k}=0.01458(10-\mathrm{pH}) & \mathrm{pH}<6.8 \\
\mathrm{k}=0.0457 & 6.8<\mathrm{pH}<7.3 \\
\mathrm{k}=0.0256(\mathrm{pH}-5.13) & \mathrm{pH}>7.3
\end{array}
$$

This correlation was used to assess the potential for pitting in $\mathrm{pH} 9$ solution as the collected sump water outside the containment building beneath the reactor averaged 9.3 over the past 3 years.

Values for the exponent "a" depend on the material and the soil. Extensive studies by Logan [Logan, 1939] indicate that for wrought iron and carbon steels "a" ranged from 0.08 to 0.32 with a mean value of 0.15 . A value of 0.15 was used in estimating pitting in this study.

The choice of the area, A, has to be balanced with the assumptions of the number of penetrating pits per unit area. Use of a large value for A will provide a better estimate of the largest penetrating pit. However, for estimation of breached area, the average pit depth for penetrating pits is the most relevant parameter. Thus, if a high value for the number of penetrating pits per unit area is selected, the average depth of this pit will be smaller than if a low value is selected. A value of $10^{4} \mathrm{~cm}^{2}\left(1 \mathrm{~m}^{2}\right)$ is used for the area correction factor. This is less than the actual area of the ICI sump, however use of the actual area would be inappropriate for these calculations. The area-scaling factor is used to find the maximum pit over a sample area. Therefore, use of the actual area would give an estimate of the single largest pit. In this calculation, the objective is to calculate the area breached by pitting, not the largest pit, and an estimate of the average size of a penetrating pit is the appropriate value. This calculation assumes that there are between 0.05 and $0.5\left(\mathrm{~cm}^{2}\right)^{-1}$ pits. Therefore, using the maximum pit depth from a $1 \mathrm{~m}^{2}$ area, where there are between 500 and 5000 penetrating pits is believed to provide a conservative estimate of breached area.

\section{Pitting Corrosion Modeling Results}

The model and parameters described above were used to estimate potential pitting rates through the 3/8-inch carbon steel liner. Figure 5 presents the maximum pit depth as a function of time and soil aeration conditions and contrasts this with the liner thickness. From the liner thickness, the approximate time of first penetration as a function of soil aeration was estimated: 40 years for very poor aeration, 135 years for fair aeration, 200 years for average pitting parameter values, 245 years for poor aeration and greater than 250 years for good aeration. 
Maximum Pit Depths as a function of soil aeration and time

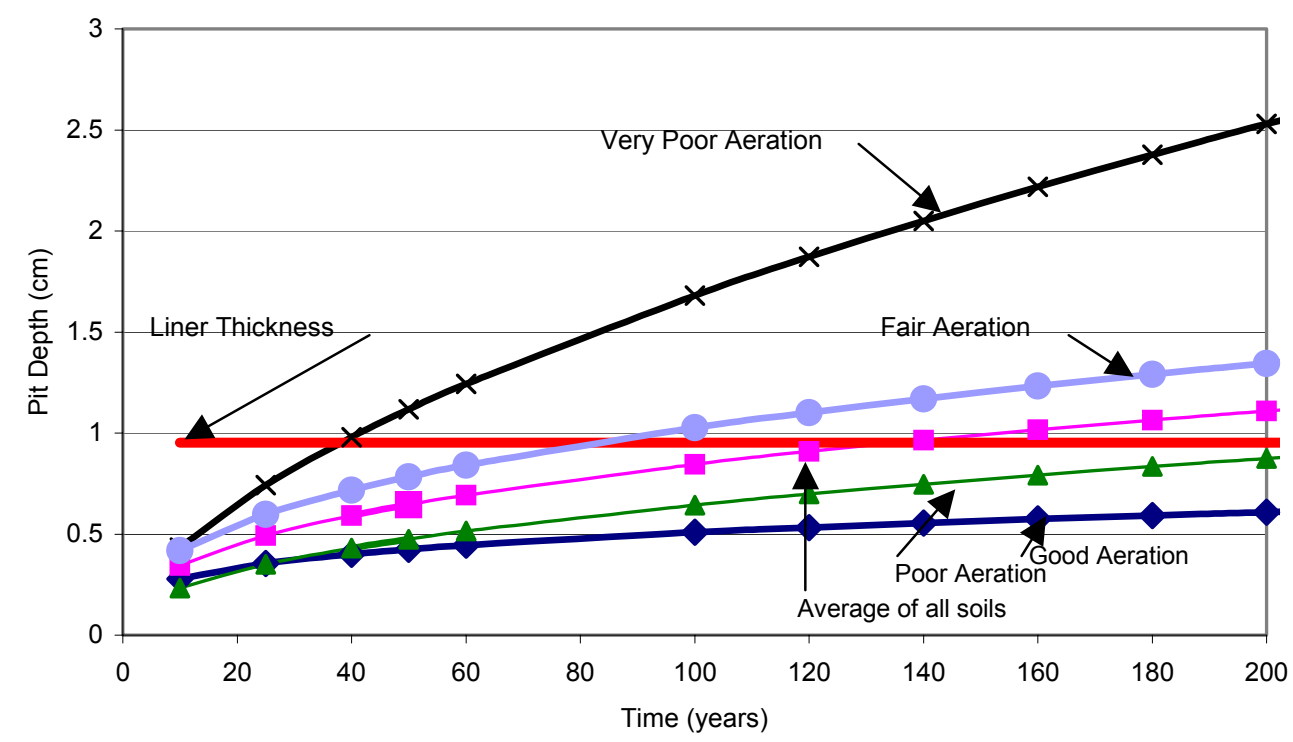

Figure 5 Predicted maximum pit depths as a function of aeration

Figure 6 presents the results for the analysis of area breached as a function of the number of penetrating pits per unit area. The two most aggressive soil conditions, Very Poor and Fair Aeration were simulated. The results indicate that if there are 0.5 penetrating pits $/ \mathrm{cm}^{2}$, pitting will rapidly consume the liner. In the very poor aeration case, $7 \%$ is breached at 40 years, $53 \%$ is breached by 50 years and $100 \%$ is breached by 60 years. At 0.05 penetrating pits $/ \mathrm{cm}^{2}$, it takes 100 years since the time of first penetration to corrode all of the metal. The rate of pitting in fair soils is slower than in very poor soils and therefore, the effects are less pronounced but similar. For the high pit density, $0.5\left(\mathrm{~cm}^{2}\right)^{-1}$, the first penetration occurs at 135 years and pits are predicted to penetrate $83 \%$ of the area by 250 years. For the lower density of penetrating pits, only $8 \%$ of the area is predicted to have pitted through by 250 years. 
Fractional Area as a Function of Number of Pits per Unit Area

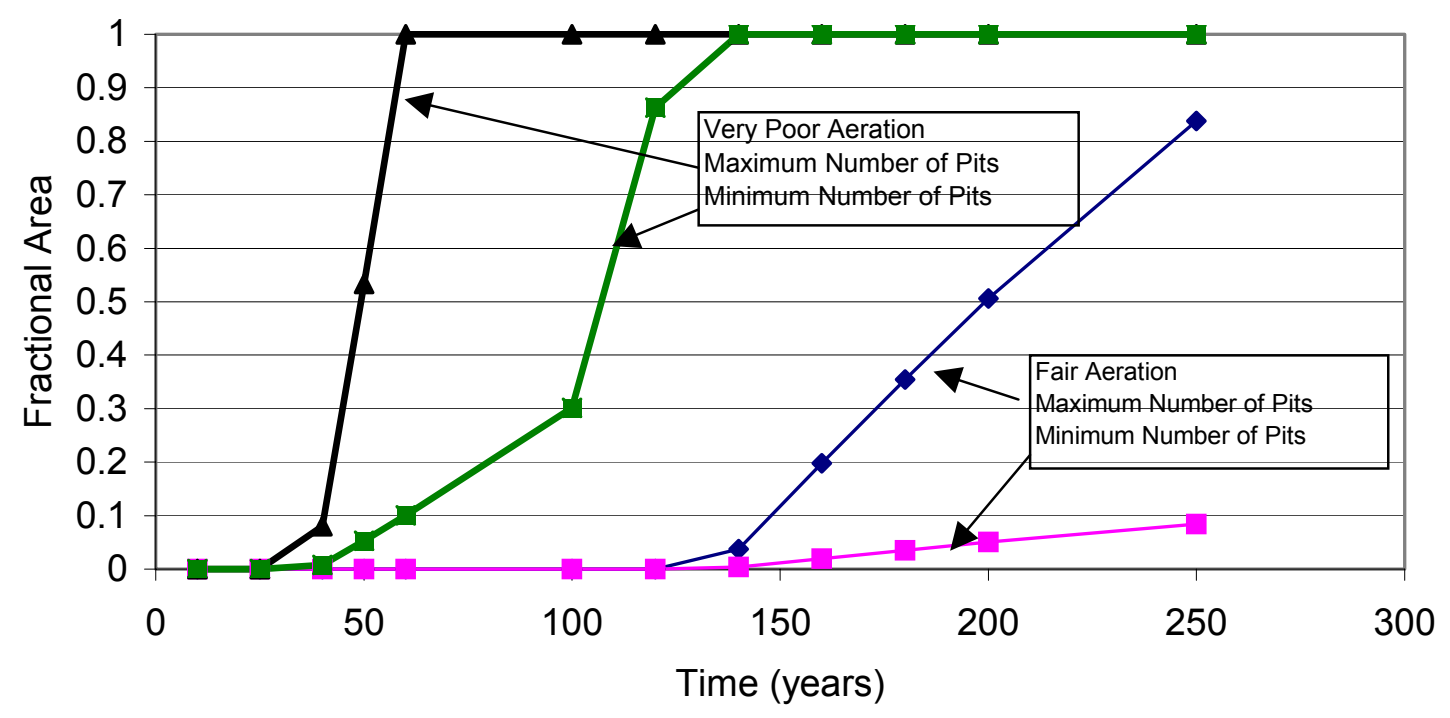

Figure 6 Fractional areas penetrated by pits as a function of pit density for very poor and fair aeration soils.

The third variable examined for its impacts on pitting was $\mathrm{pH}$. It is likely that the $\mathrm{pH}$ of the water contacting the carbon steel liner will be around 9 based on data collected from the ICI sump. The exponent $\mathrm{k}$ was estimated using the correlation with $\mathrm{pH}$ for $\mathrm{pH}$ between 7 and 11 . The correlation is linear and increasing with $\mathrm{pH}$. Extrapolation up to $\mathrm{pH} 11$ is suspect as the soil data maximum $\mathrm{pH}$ was 9.3, similar to the values found in the ICI sump. However, this was performed to get a worst-case estimate of the impacts of $\mathrm{pH}$ on pitting. The other parameters used were identical to that for the fair aeration soil (exponent $n$ is 0.39 ). Figure 7 shows the results of the analysis. The model indicates that at high $\mathrm{pH}$ pitting corrosion may lead to early failure of the container. At $\mathrm{pH} 7$, the model predicts that pits have not penetrated the container for 250 years. At $\mathrm{pH} 9$, the first penetration occurs at 95 years and the entire liner would be corroded away by 185 years. This is slightly faster than the previous case because the pitting parameter $\mathrm{k}$ is approximately $15 \%$ higher at $\mathrm{pH} 9$ than the average value. At $\mathrm{pH} 11$, the $\mathrm{k}$ is estimated to be 0.15 as compared to the average value of 0.086 . This causes the predicted first penetration to occur after 33 years and complete corrosion of the liner would occur within 75 years. 
Fraction of Area Breached due to Pitting

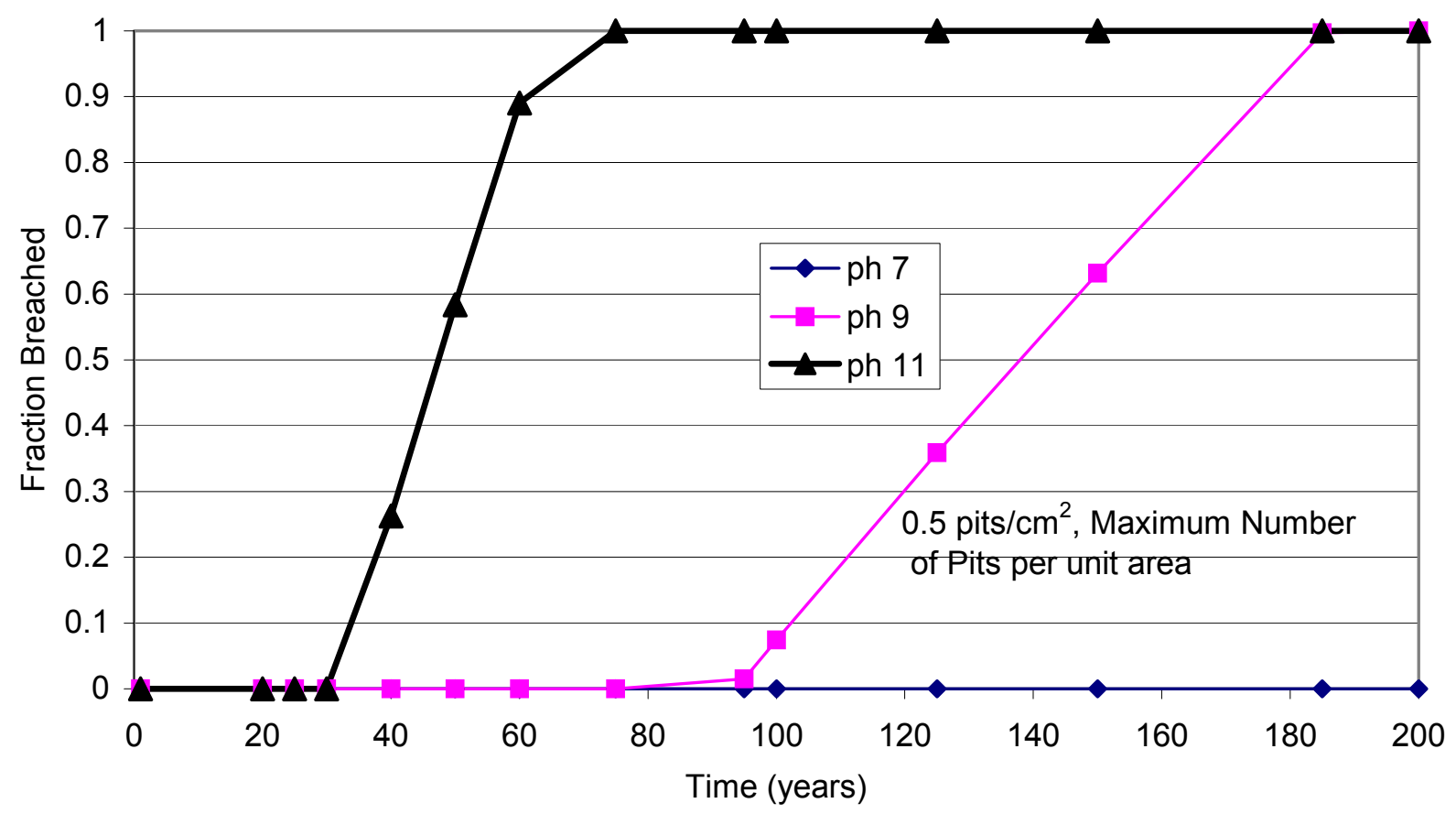

Figure 7 Predicted fractional area penetrated by pitting as a function of $\mathrm{pH}$.

\section{$\underline{\text { Selection of Container Lifetimes for Release Analysis }}$}

The preceding analysis on corrosion of carbon steel suggests lifetimes on the order of a few hundred years under conditions likely to occur at the Maine Yankee site. Using the average corrosion rate for all soils suggests a lifetime of 168 years with a range of 50-1200 years. First penetration by pitting is also predicted to occur at 200 years, based on the average values for pitting rates, with a range of 35 to greater than 250 years. Additionally, a lifetime of 57.8 years was estimated for the protective paint on the liner.

These analyses did not account for combination of general corrosion and pitting. Therefore, the lifetime is likely to be lower than the predicted values. For the purposes of examining potential releases from the activated concrete, lifetime estimates of $0,25,50$, and 100 years will be used. Instantaneous failure, equivalent to removal of the liner, is an unrealistic assumption but provides an upper bound on the maximum release. A lifetime of 25 years is also felt to be unrealistically low because the protective paint liner is expected to last more than 50 years before corrosion can start. Even if the protective layer fails earlier, the highest pitting rates suggest 35 years before penetration and the highest corrosion rates suggest 50 years before complete consumption of the liner. Thus, even in combination it is likely that the liner will last more than 25 years. In addition, the high general and pitting corrosion rates occurred in environments that are known to be more aggressive to carbon steel than the environment anticipated at Maine Yankee. The lifetimes of 50 and 100 years are used to explore the range of impacts of lifetime 
on release. Although the liner may last more than 100 years, releases will be insensitive to longer lifetimes because short-lived radionuclides, for example $\mathrm{H}-3$, will have undergone substantial decay. Long-lived radionuclides such as C-14 will not undergo substantial decay unless the liner lasts more than 1000 years.

\section{Diffusion Controlled Release}

Previous estimates of release assumed that the entire inventory was released from the concrete into the contacting water instantly. This is extremely conservative as there are several studies that show release is controlled by diffusion or solubility. Therefore, a more realistic conceptual model for estimating release from the activated concrete assumes diffusion is the rate controlling mechanism. A one-dimensional finite difference model was set up to represent the system as shown in Figure 8. The DUST code was used to perform the analysis (Sullivan, 1993).

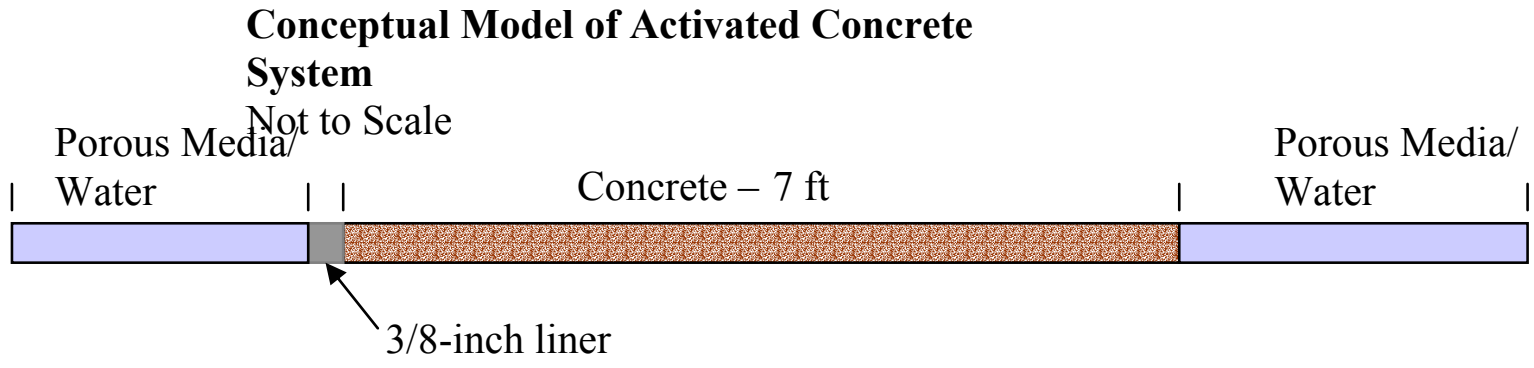

Figure 8 Schematic diagram of the one-dimensional model used to simulate release from the waste form.

In the porous media/water regions surrounding the concrete, the diffusion coefficient was set to $10^{-5} \mathrm{~cm} 2 / \mathrm{s}$ to provide rapid transport away from the concrete and thereby enhance the predicted rate of release. Prior to failure of the liner, it was modeled as a region with a very low diffusion coefficient $\left(\mathrm{D}=10^{-14} \mathrm{~cm}^{2} / \mathrm{s}\right)$ that effectively prevents diffusion through the liner. After the designated container lifetime, the diffusion properties of the liner were increased to that of the surrounding porous media. The diffusion coefficient of the radionuclide in the concrete is discussed later.

In translating the conceptual model geometry into a finite difference model, the concrete region was modeled with $1 / 4$ inch $(0.635 \mathrm{~cm})$ cells. The liner was modeled as two $3 / 16$-inch $(0.48 \mathrm{~cm})$ cells. The normalized inventory depicted in Figure 4 was used as the initial condition for the distribution of contaminants.

\section{Key Radionuclides}

In the License Termination Plan Cs-134, Co-60, C-14, Eu-152, Eu-154, Fe-55, H-3, and Ni-63 were identified as the radionuclides in the activated concrete (Table 1). In these analyses H-3 and $\mathrm{C}-14$ are simulated. $\mathrm{H}-3 \mathrm{had}$ the highest inventory and the highest predicted dose for the inventory distribution in the concrete. C-14 is considered because of its long half-life and relatively high predicted dose for the inventory distribution. In the current analyses releases are 
reported in terms of the fraction of the total inventory in the activated concrete. This will permit scaling of the results to the actual measured inventory. H-3 will have as high or higher mobility than any other radionuclide and can serve as an upper bound to release of all radionuclides with a shorter half-life and Eu-152, which has a slightly longer half-life (13.4 years). Although Eu-152 has a longer half-life than $\mathrm{H}-3$, it is expected to have slower release rates from the concrete than H-3 and will also sorb to the surrounding porous medium and $\mathrm{H}-3$ will not. Therefore, the dose impacts from Eu-152 per unit inventory will be much lower than for H-3. Thus, the only radionuclide not bounded by this analysis is $\mathrm{Ni}-63$. This is not believed to be a major issue as the predicted dose impact for Ni-63 is four orders of magnitude less than that of H-3.

\section{Experimental Diffusion Coefficients}

A few studies have been conducted for the diffusion of H-3 and C-14 in cement. Literature values for H-3 diffusion range from $610^{-9} \mathrm{~cm}^{2} / \mathrm{s}$ to $5.510^{-7} \mathrm{~cm}^{2} / \mathrm{s}$ (Dayal, 2003, Serne, 2001, Matsuzuro, 1976, Szabo, 2002). For the purposes of analysis, three diffusion coefficients will be used $\mathrm{D}=10^{-6}, 5.510^{-8}$, and $10^{-8} \mathrm{~cm} 2 / \mathrm{s}$. The largest value represents the highest transport rate, as it is larger than any measured value. The second value represents a mid-range value from all of the data and the third value is a value on the low end of the range of measured data. These three values were chosen to examine the range of conditions that could be expected to occur.

Carbon-14 movement in cement is a complicated geochemical issue. In cement chemical environments, carbon often forms carbonates and is not readily transported through the cement. A few experiments have estimated diffusion coefficients based on leaching data. The estimated diffusion coefficient values range from $710^{-15}$ to $110^{-12} \mathrm{~cm}^{2} / \mathrm{s}$ (Habeyab, 1985, Serne, 2001). These values suggest that $\mathrm{C}-14$ is not mobile in cement systems. For the analyses in this study, a value $10^{-12} \mathrm{~cm}^{2} / \mathrm{s}$ was used. This should provide an upper bound estimate of C-14 releases.

\section{Predicted H-3 and C-14 Release Rates and Cumulative Release}

The data values for initial distribution, diffusion coefficients, and liner lifetimes were used in a series of analyses that examined the normalized annual release rate and cumulative fractional release from the activated concrete. Three major categories, instantaneous liner failure, liner intact for all times, and liner completely failed after a specified time were analyzed. The instantaneous failure provides an upper bound on release. The liner intact for all times provides an upper bound estimate on release out of the unlined section of concrete. In addition, it provides information on the potential redistribution of contaminants prior to liner failure and may help interpret current distributions of $\mathrm{H}-3$ in the activated concrete. The fixed liner lifetime analyses provide more realistic evaluations of what will occur.

\section{Instantaneous Liner Failure}

\section{Tritium}

As an upper bound on potential releases, the liner was assumed to fail instantly. Figure 9 presents the cumulative fractional release of $\mathrm{H}-3$ from the activated concrete with an instantaneous failure of the liner for the three selected values of the diffusion coefficient $\left(D=10^{-}\right.$ ; $5.510^{-8}$; and $10^{-8} \mathrm{~cm}^{2} / \mathrm{s}$ ). The results indicate a large fraction of the inventory is released 
within the first few years. Due to depletion and radioactive decay release is essentially complete within 30 years. The high release rate occurs because for inventory distribution used in the analysis, Figure 1, 49\% of the mass is within 2 inches and $99 \%$ is within 12 inches of the surface adjacent to the liner.

Tritium Cumulative Fractional Release

No liner

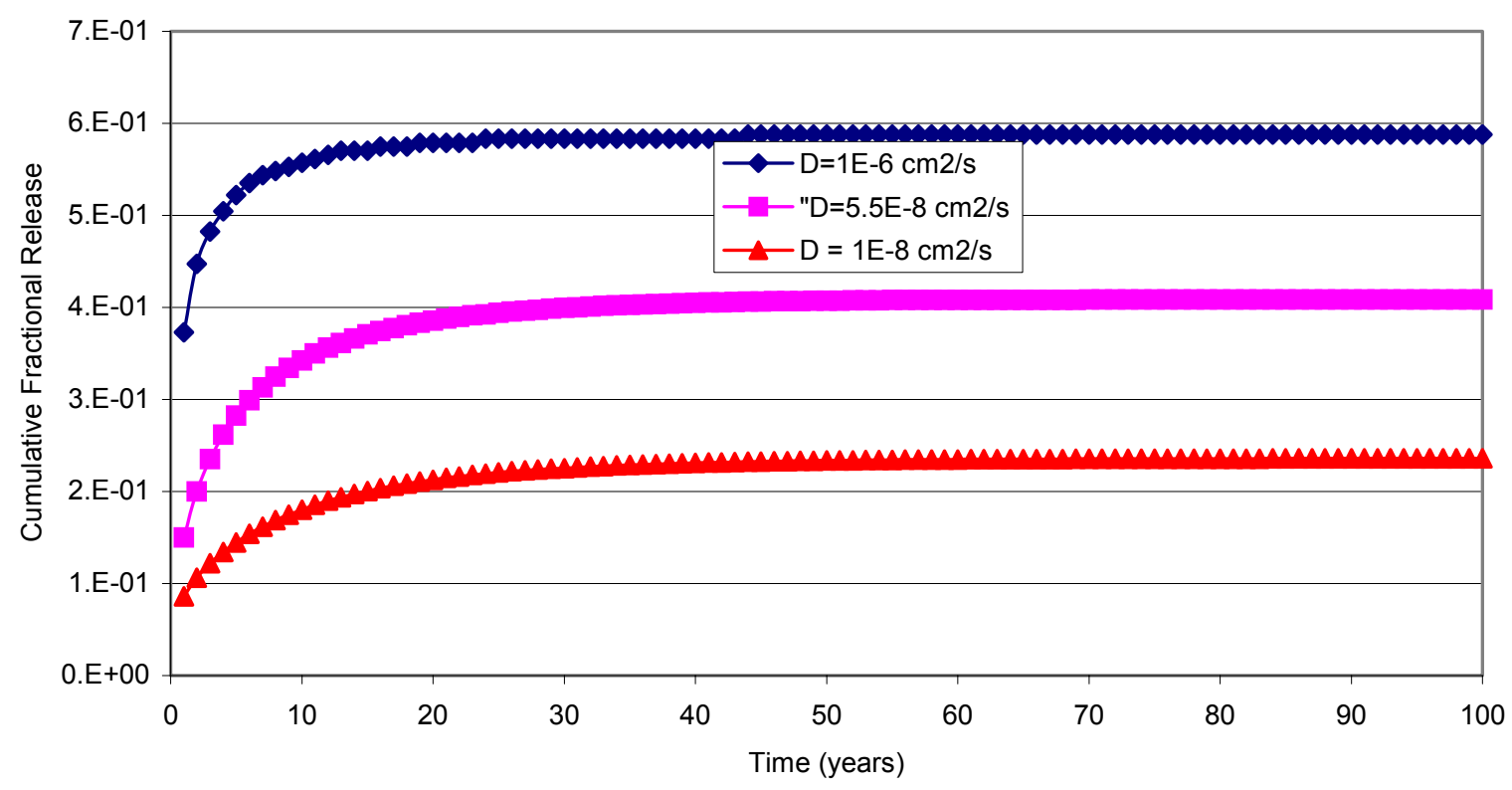

Figure 9 Cumulative fractional release for $\mathrm{H}-3$ in the case of no liner and three values for the diffusion coefficient.

Figure 10 presents the annual fractional release rate for the three values of the diffusion coefficient. This graph indicates that the peak release is always in the first year and declines rapidly as the source is depleted. It is interesting to note that the case with the largest diffusion coefficient, D, after about 10 years, has a lower release rate than the lower diffusion coefficients. This is a result of the rapid depletion of the high concentration zone near the surface for the higher value for $\mathrm{D}$. In all cases, the release rate declines by more than an order of magnitude within 10 years. 
Tritium Fractional Release Rate High concentration side

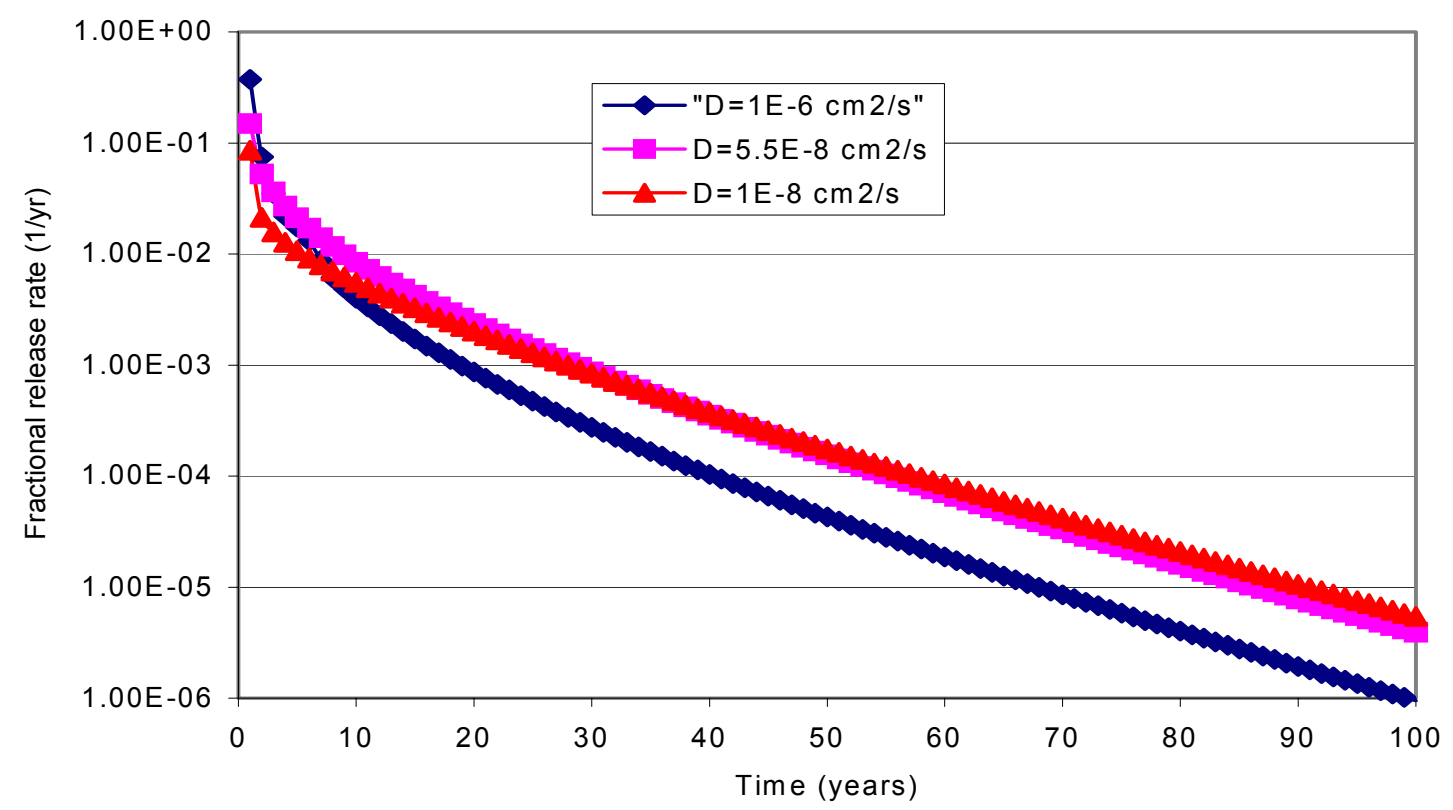

Figure 10 Annual release rates over time in the case of no liner and three values for the diffusion coefficient.

The ultimate concern is the amount of radioactivity in the contacting solution, as groundwater is the pathway for human exposure. To obtain an upper bound estimate, it was assumed that everything released remained in solution subject to radioactive decay (i.e. transport processes were not fast enough to move contaminants out of the area). For H-3 due to its short half-life, there will be a brief period when the concentration in solution builds up until the decay of the mass in solution exceeds the amount released per year. At that time, the inventory in solution will decrease in time. Figure 11 shows the fractional inventory in solution for the three values of diffusion coefficient. 
Tritium Cumulative Fraction in Solution

No liner

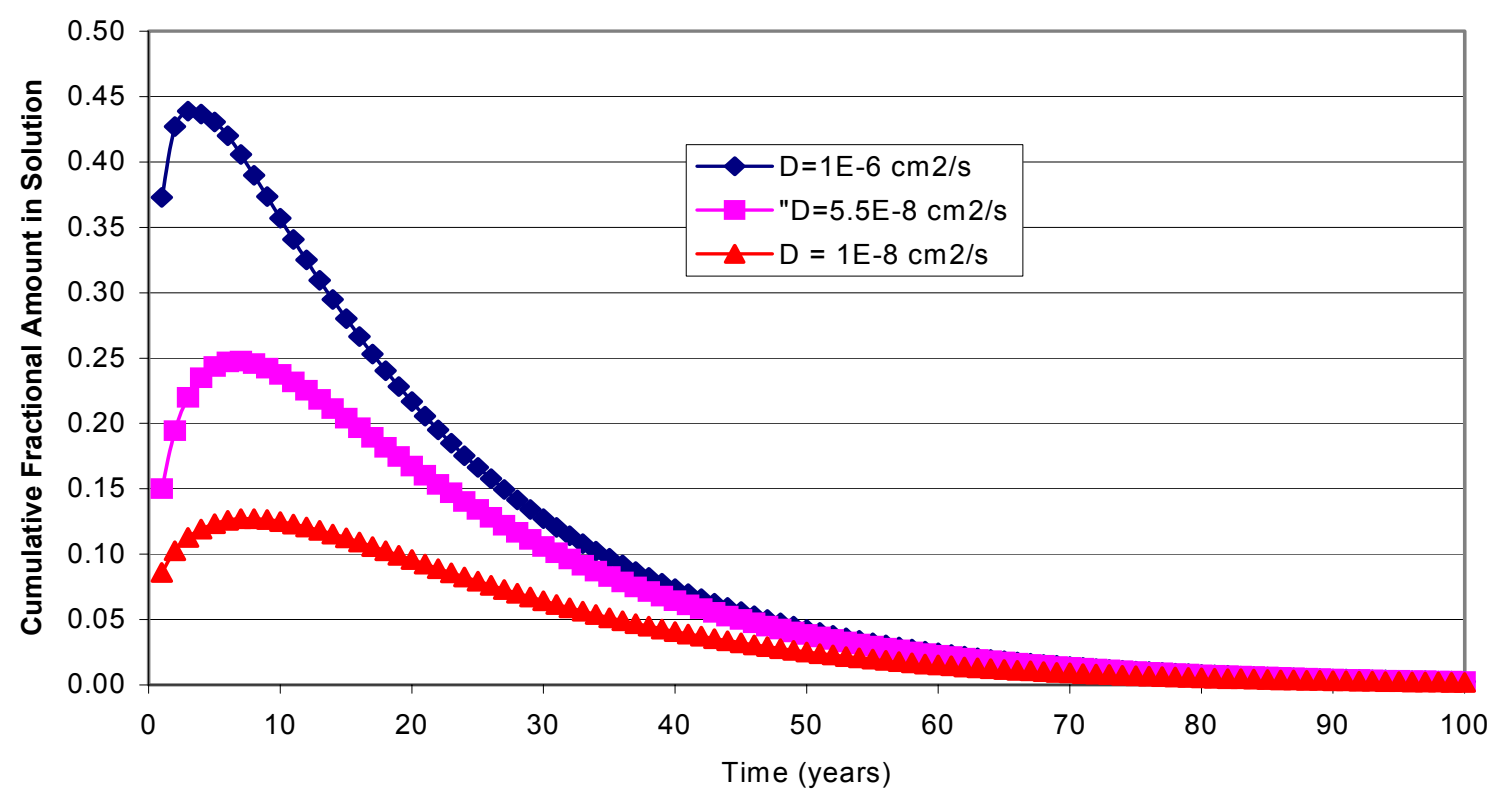

Figure 11 Cumulative fractional amount in solution.

Table 4 summarizes the total cumulative fractional release, peak fractional release rate, and maximum fraction in solution for the three cases when a liner is not present. The maximum amount in solution for H-3 is only slightly greater than the maximum annual release as result of radioactive decay and the decrease in release rates over time. The ratio of maximum in solution divided by maximum annual release never exceeded a value of 1.6.

Table 4: Summary of maximum annual, cumulative, and fraction in solution for H-3 in the case of no liner.

\begin{tabular}{|l|c|c|c|}
\hline & $\begin{array}{l}\text { Maximum Annual } \\
\text { Fractional Release }\end{array}$ & $\begin{array}{l}\text { Cumulative } \\
\text { Fractional Release }\end{array}$ & $\begin{array}{l}\text { Maximum Fractional } \\
\text { Amount in Solution }\end{array}$ \\
\hline $\mathrm{D}=10^{-6} \mathrm{~cm}^{2} / \mathrm{s}$ & 0.37 & 0.59 & 0.44 \\
\hline $\mathrm{D}=5.510^{-8} \mathrm{~cm}^{2} / \mathrm{s}$ & 0.16 & 0.41 & 0.26 \\
\hline $\mathrm{D}=110^{-8} \mathrm{~cm}^{2} / \mathrm{s}$ & 0.09 & 0.25 & 0.13 \\
\hline
\end{tabular}

Similar analyses were performed for the concrete that is always intact with groundwater on the side away from the liner. Due to its much lower concentration (approximately $1 / 3000^{\text {th }}$ of the peak concentration) releases were substantially lower from this side. For $D=10^{-6} \mathrm{~cm}^{2} / \mathrm{s}$, peak release rates were less than $2.210^{-4}$ and the peak cumulative fractional release was $8.110^{-4}$. Lower release rates and cumulative fractional release were obtained for the lower values of D. 


\section{Carbon-14}

For the instantaneous liner failure case, the cumulative fractional release near the liner is presented in Figure 12. The predicted fractional release in the first year is greater than $4 \%$ of the inventory. This is unreasonably high for a diffusion coefficient of $10^{-12} \mathrm{~cm}^{2} / \mathrm{s}$. Analytical models for diffusion release [Pescatore, 1991] from a $15 \mathrm{~cm}$ thick rectangular geometry with a uniform concentration suggest a release of less than $0.1 \%$ during the first year and less than $2.6 \%$ over 1000 years. This model allows diffusion out both sides and therefore, is equivalent to assuming a thickness of $7.5 \mathrm{~cm}$ for the one-sided case. In other words, $100 \%$ of the inventory is within $7.5 \mathrm{~cm}$ ( 3 inches of the surface). The cause of this discrepancy is numerical simulation error at the interface between the activated concrete and the contacting porous media. In DUST, the diffusion coefficient used to estimate transport is the average of the diffusion coefficient in two adjacent finite-difference control volumes. Thus, at the interface, where the diffusion coefficient changes from $10^{-12} \mathrm{~cm}^{2} / \mathrm{s}$ in the activated concrete to $10^{-6} \mathrm{~cm}^{2} / \mathrm{s}$ in the porous medium, the code uses a value of $0.510^{-6} \mathrm{~cm}^{2} / \mathrm{s}$. This effectively makes the first control volume of the activated concrete have a diffusion coefficient that is $1 / 2$ the value of the porous media and almost six orders of magnitude greater than intended. This causes the first control volume, which contains $5.7 \%$ of the total inventory, to empty rapidly leading to the predicted high release.

\section{Carbon-14 cumulative fractional release No liner}

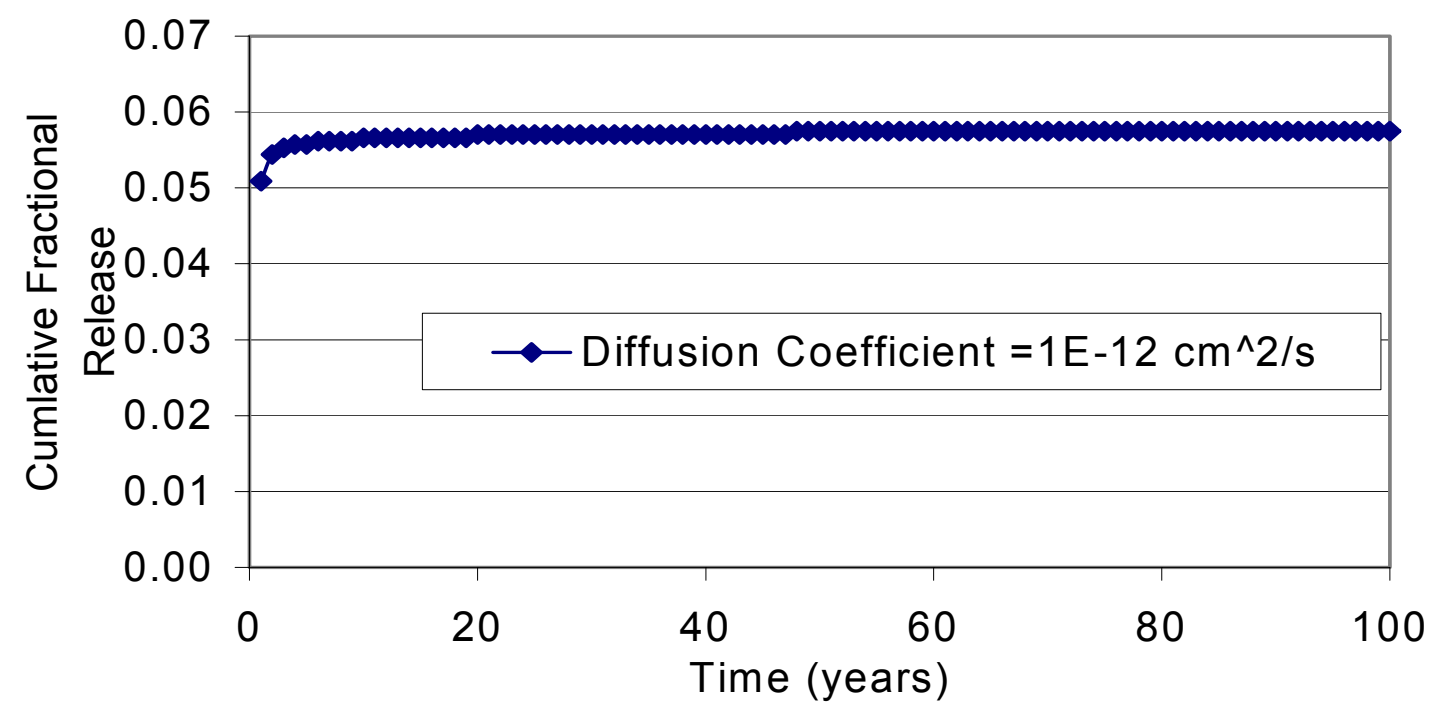

Figure 12 Cumulative fractional release for $\mathrm{C}-14$ in the absence of a liner.

Figure 13 presents the annual fractional release rate for C-14. The rapid decrease from $4 \%$ in the first year to less than $10^{-3} \%$ within 20 years reflects the rapid draining of the first computational cell due to the numerical simulation model. The lower rates at the longer times are more representative of diffusion out of a low diffusion region. 
Carbon-14 Fractional Release Rate

No liner

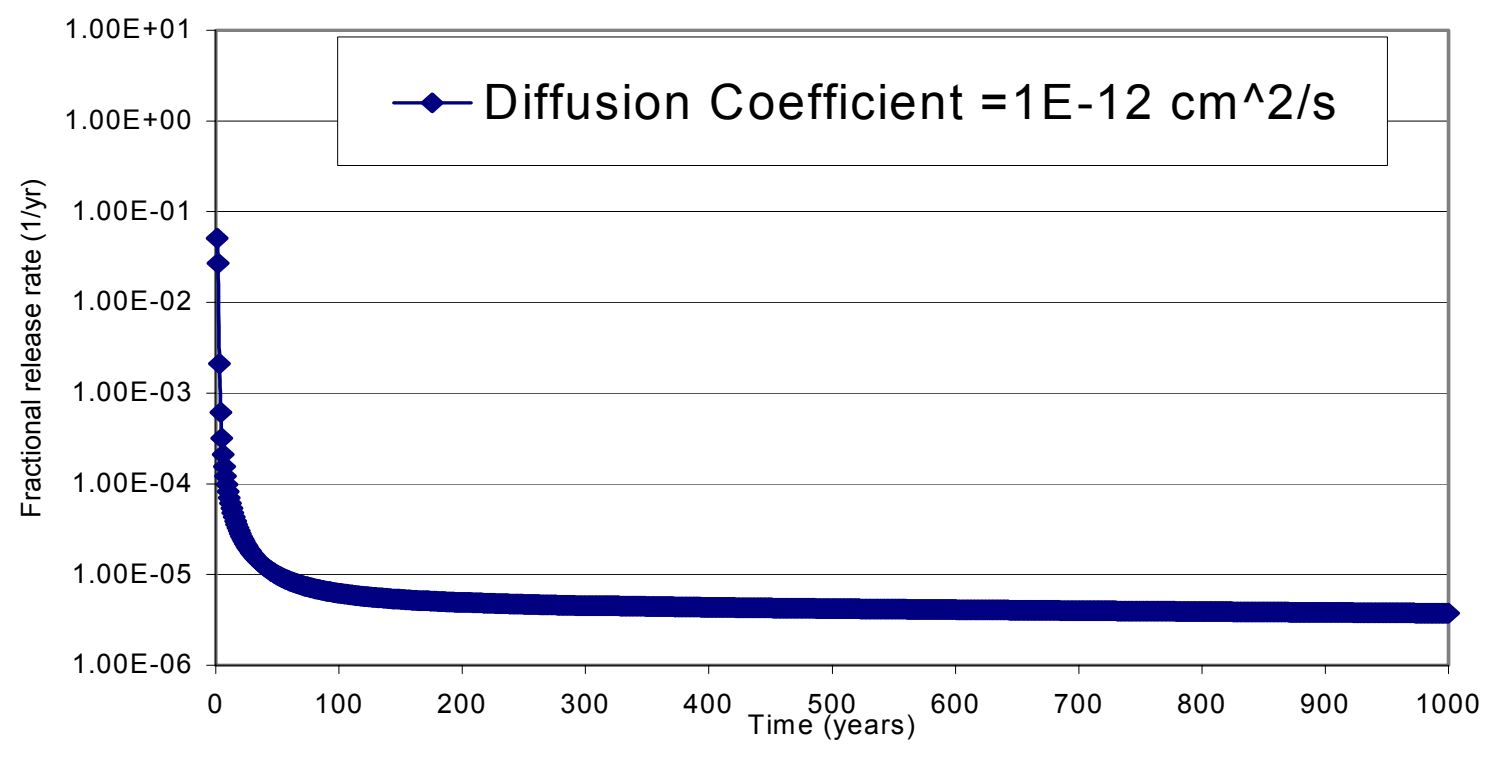

Figure 13 Annual fractional release rate predicted for C-14.

To remove this unintended numerical consequence, an additional $0.6 \mathrm{~cm}$ long volume was introduced between the liner and the activated concrete. The diffusion coefficient for this region was set to $10^{-12} \mathrm{~cm}^{2} / \mathrm{s}$, the value for the activated concrete. This forced the value of the diffusion coefficient in the activated concrete to remain at $10^{-12} \mathrm{~cm}^{2} / \mathrm{s}$ in the finite difference simulation. In this case, the predicted release over 1000 years was only $0.4 \%$. This is similar in magnitude to the analytical solution and is felt to be more representative of actual releases.

For the remainder of the paper, the diffusion model in DUST will be used to generate the results for $\mathrm{C}-14$ recognizing that they will provide extremely high estimates of release at the liner side.

Due to the long half-life for $\mathrm{C}-14$, the cumulative fractional release provides a reasonable estimate of the maximum amount that could be in solution at any time.

\section{Liner Intact}

If the liner is intact, the contaminants have to diffuse through the 7 feet of concrete to be released from the other side. Due to the short half-life of tritium, releases are extremely low from this side for any value of the diffusion coefficient. Due to the low diffusion coefficient for C-14, the releases are also very low. The maximum release for both $\mathrm{H}-3$ and $\mathrm{C}-14$ at the unlined side of the concrete arises from the assumption that the concentration has a minimum value of $1 \mathrm{pCi} / \mathrm{g}$. Table 5 summarizes the maximum fractional annual release and the cumulative release over the 1000-year simulation period. 
Table 5: Maximum total and annual fractional release for an intact liner.

\begin{tabular}{|l|c|c|}
\hline & Maximum Annual Fractional Release & Cumulative Fractional Release \\
\hline H-3 & $210^{-5}$ & $9.010^{-4}$ \\
\hline C-14 & $210^{-5}$ & $2.410^{-5}$ \\
\hline
\end{tabular}

An interesting consideration is the possible redistribution of $\mathrm{H}-3$ while the liner is intact. This may be important in understanding the current distribution of $\mathrm{H}-3$ in the activated concrete as several years have passed since the end of operation. Figures 14 and 15 show the redistribution of $\mathrm{H}-3$ if the diffusion coefficient is $10^{-6} \mathrm{~cm}^{2} / \mathrm{s}$ and $10^{-8} \mathrm{~cm} 2 / \mathrm{s}$. At the higher diffusion coefficient, redistribution is rapid and the peak concentration moves from a depth of two inches to the surface within 1 year. For the lower value of the diffusion coefficient, the redistribution is much slower and even after 10 years, the peak remains at a depth of 2 inches.

Tritium Concentration Profile

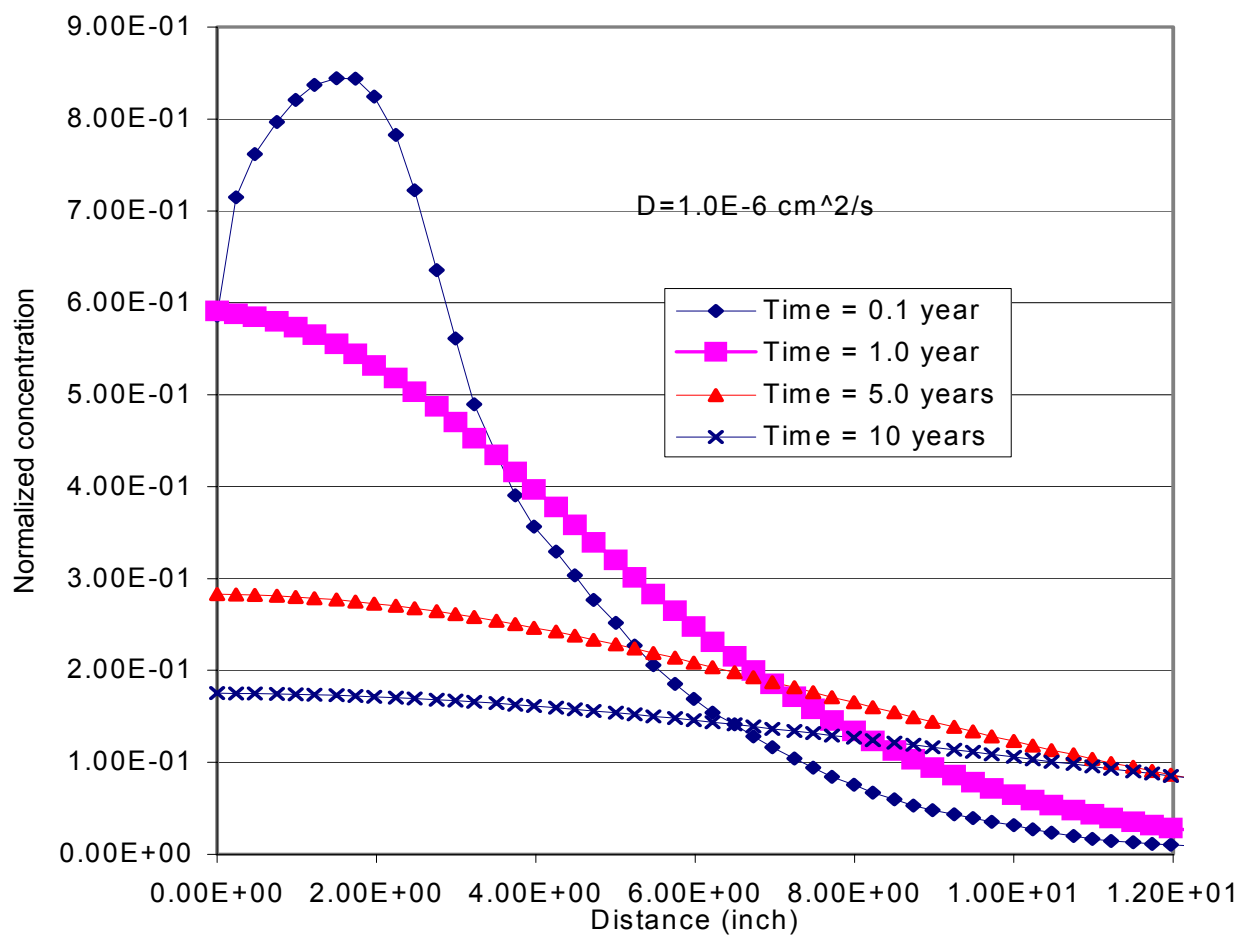

Figure 14 Predicted redistribution of tritium with liner intact and $D=10^{-6} \mathrm{~cm}^{2} / \mathrm{s}$. 
Tritium Concentration Profile

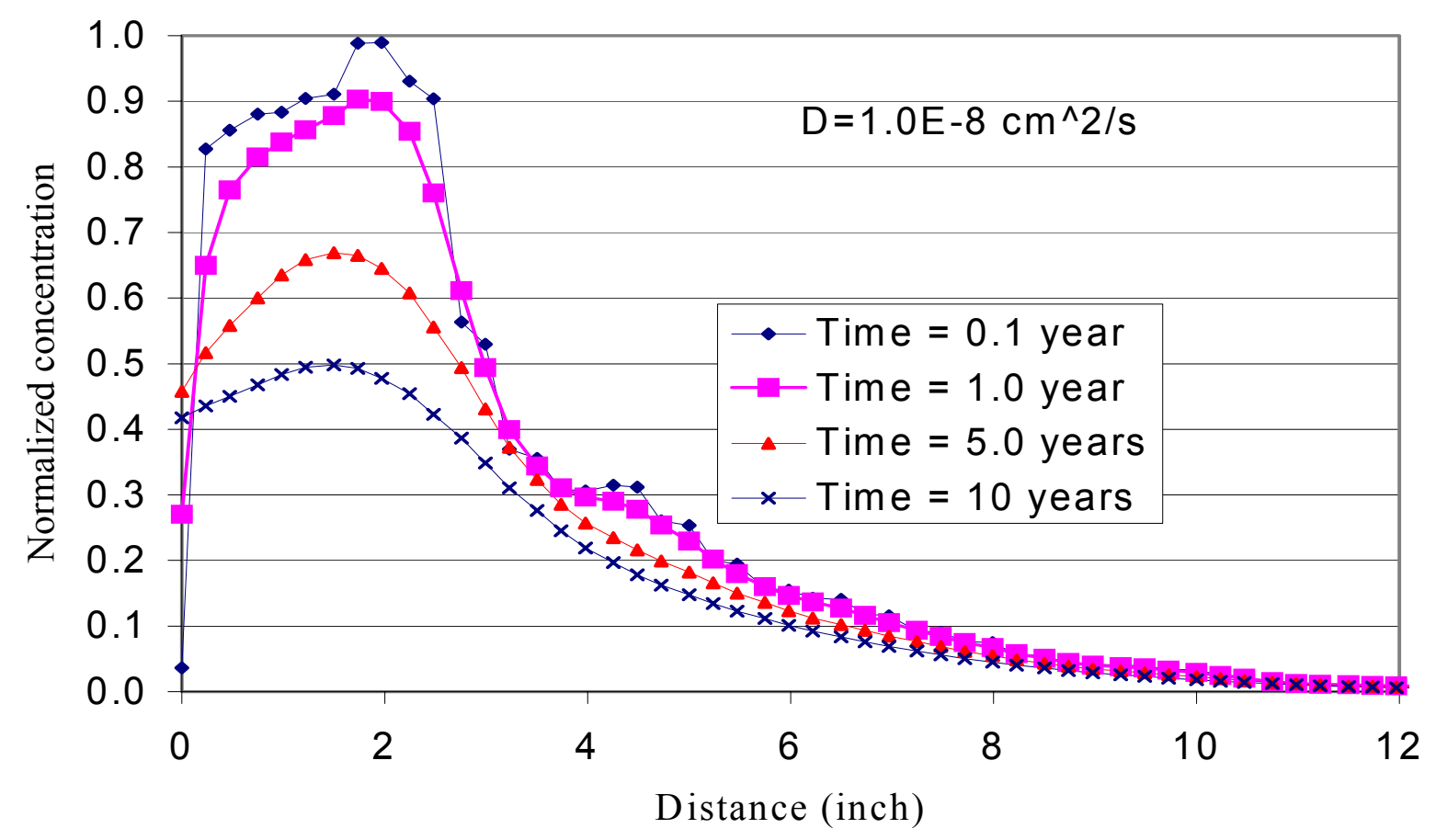

Figure 15 Predicted redistribution of tritium with liner intact and $D=10^{-8} \mathrm{~cm}^{2} / \mathrm{s}$.

\section{Effect of Liner Failure Time}

\section{Tritium}

The corrosion modelling suggested a liner time of at least 100 years if credit was taken for the protective paint. Considering combination of pitting and general corrosion suggested that lifetimes of 25, 50, and 100 years be examined to determine the effect of failure time. Twentyfive years is believed to be an extremely conservative estimate of lifetime. To simulate this, it was assumed that the liner would be intact until the failure time and diffusion through the liner would be very slow $\left(D=10^{-14} \mathrm{~cm}^{2} / \mathrm{s}\right)$. At this time, the liner was assumed to provide no barrier to release and the effective diffusion coefficient was changed to that of the surrounding porous medium $\left(\mathrm{D}=10^{-5} \mathrm{~cm}^{2} / \mathrm{s}\right.$ for $\mathrm{H}-3$ and $\mathrm{D}=10^{-6} \mathrm{~cm}^{2} / \mathrm{s}$ for $\left.\mathrm{C}-14\right)$.

Figure 16 provides the cumulative fractional release for the 25 -year liner lifetime. The figure contains the predicted cumulative fractional release for three values of the diffusion coefficient $\left(\mathrm{D}=10^{-6}, 5.510^{-8}\right.$, and $\left.10^{-8} \mathrm{~cm}^{2} / \mathrm{s}\right)$. Two important differences occur from when the liner fails instantly. First, total releases are much lower. Second, the $\mathrm{D}=10^{-6} \mathrm{~cm}^{2} / \mathrm{s}$ simulation does not release the maximum amount, the $\mathrm{D}=5.510^{-8} \mathrm{~cm}^{2} / \mathrm{s}$ case does. The cause for this is while the liner is intact, more of the mass has moved away from the liner at the higher diffusion coefficient. Figure 17 shows the annual fractional release for the 25 -year liner lifetime. It can be 
seen that after the first few years, the annual release rate is not strongly dependent on the choice of diffusion coefficient.

\section{H-3 Cumulative Fractional Release}

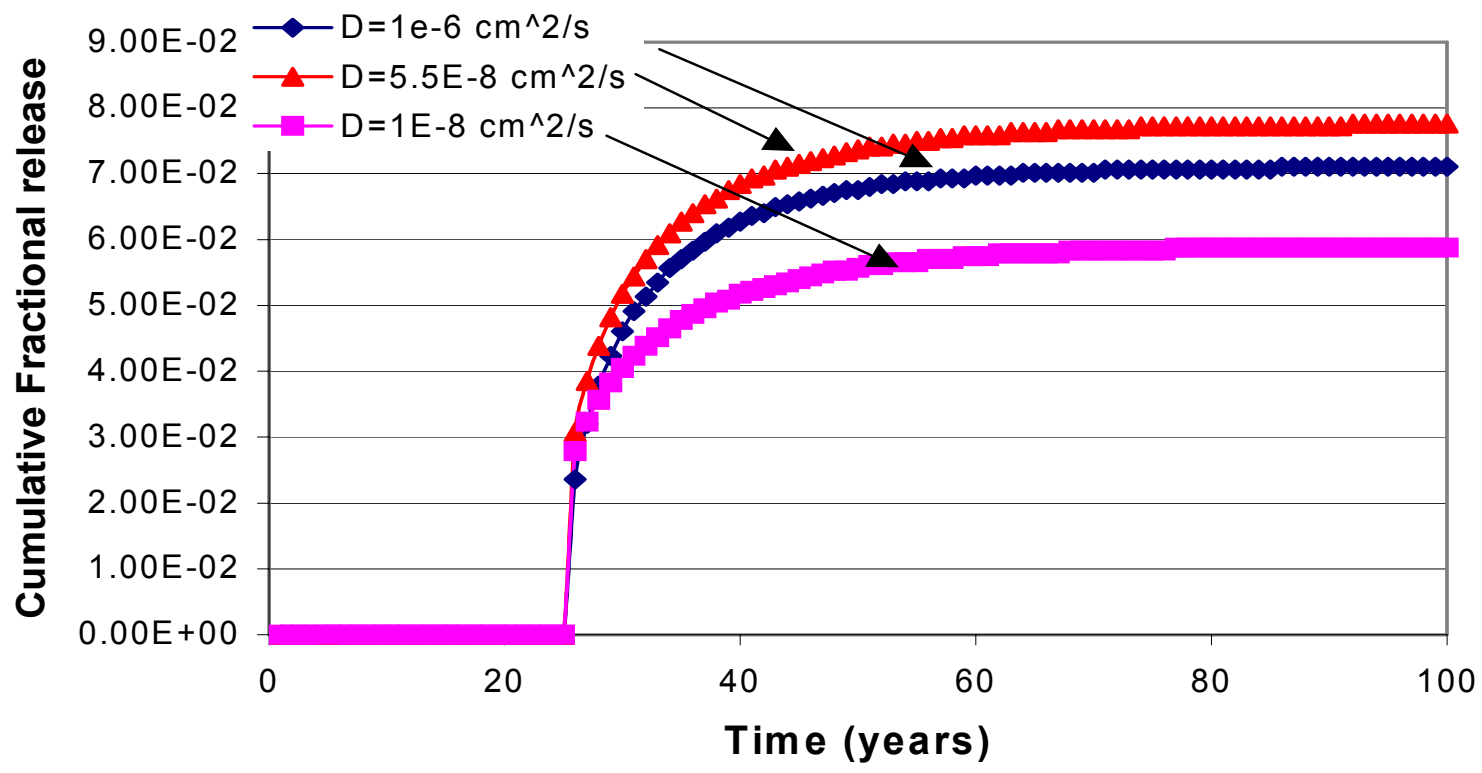

Figure 16 Cumulative fractional releases for H-3 for a 25-year lifetime liner.

H-3 Fractional Release Rate High concentration side

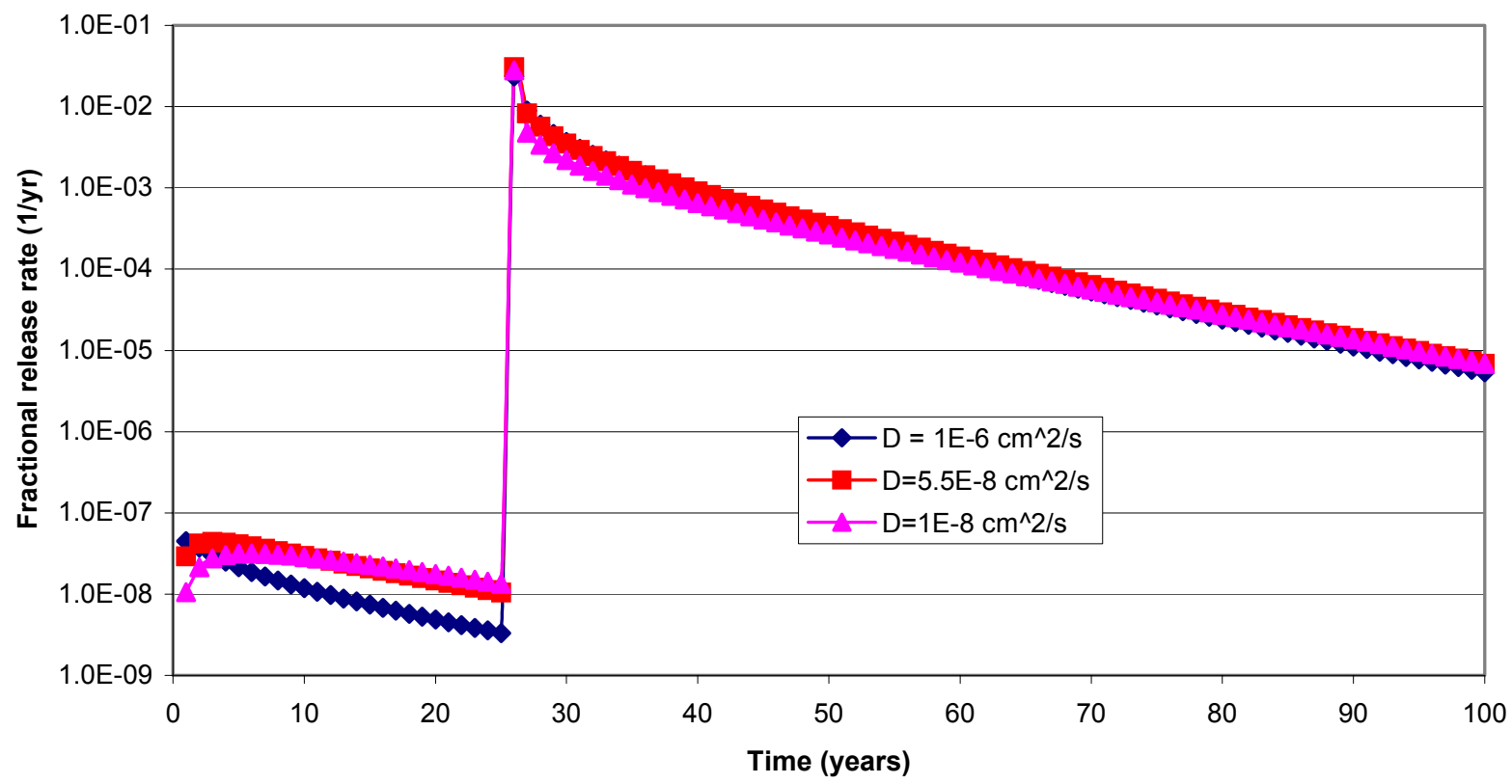

Figure 17 Annual Fractional Release for H-3 for a 25-year liner lifetime. 
Figure 18 presents the maximum annual fractional release as a function of failure time. This graphic illustrates the rapid decrease in maximum annual release as a function of time. This is due to the short half-life of tritium (12.3 years) as compared to the failure times. The importance of the liner as a protective barrier for release of tritium is clear.

Maximum yearly release as a function of liner failure time

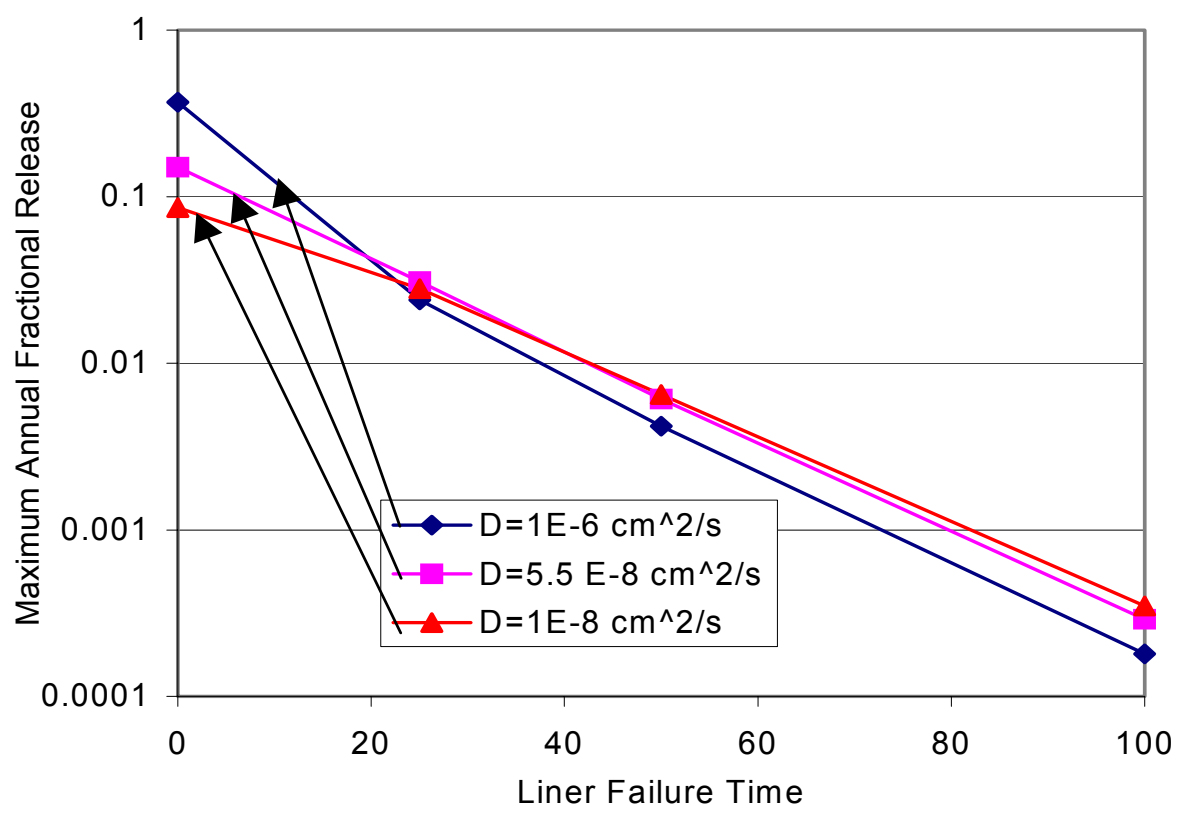

Figure 18 Effect of liner lifetime on annual fractional H-3 release.

Table 6 summarizes the cumulative and maximum annual fractional release for $\mathrm{H}-3$ at the four failure times $(0,25,50$, and 100 years) for the three diffusion coefficients. The annual fractional release values in Table 6 can be multiplied by the total inventory to estimate mass release and this value can be used in dose assessments. The table shows that after 25 years, the lowest diffusion coefficient has the highest release rates. Although the cumulative release for the $\mathrm{D}=10^{-}$ ${ }^{8} \mathrm{~cm}^{2} / \mathrm{s}$ case are always lower than for the $\mathrm{D}=5.510-8 \mathrm{~cm}^{2} / \mathrm{s}$ case. This is a result of diffusion. While the liner is intact, the higher diffusion coefficient case moves more material away from the liner. After the liner fails, some of this material diffuses back to be released at this interface. 
Table 6 Effect of Liner Lifetime on Predicted H-3 release.

\begin{tabular}{|c|l|l|l|}
\hline $\begin{array}{l}\text { Diffusion } \\
\text { Coefficient } \\
\left(\mathrm{cm}^{2} / \mathrm{s}\right)\end{array}$ & $\begin{array}{l}\text { Maximum } \\
\text { Annual } \\
\text { Fractional } \\
\text { Release }\end{array}$ & $\begin{array}{l}\text { Cumulative } \\
\text { Fractional } \\
\text { Release }\end{array}$ & $\begin{array}{l}\text { Maximum } \\
\text { Fractional Amount } \\
\text { In Solution }\end{array}$ \\
\hline \multicolumn{3}{|c|}{ Failure Time $=0$ years } \\
\hline $10^{-6}$ & 0.37 & 0.59 & 0.44 \\
\hline $5.510^{-8}$ & 0.15 & 0.41 & 0.26 \\
\hline $10^{-8}$ & 0.086 & 0.24 & 0.13 \\
\hline \multicolumn{4}{|c|}{ Failure Time $=25$ years } \\
\hline $10^{-6}$ & 0.024 & 0.071 & 0.041 \\
\hline $5.510^{-8}$ & 0.031 & 0.078 & 0.045 \\
\hline $10^{-8}$ & 0.028 & 0.059 & 0.034 \\
\hline \multicolumn{4}{|c|}{ Failure Time $=50$ years } \\
\hline $10^{-6}$ & $4.210^{-3}$ & 0.014 & $7.5 \mathrm{E}-3$ \\
\hline $5.510^{-8}$ & $6.110^{-3}$ & 0.016 & $9.0 \mathrm{E}-3$ \\
\hline $10^{-8}$ & $6.510^{-3}$ & 0.014 & $7.9 \mathrm{E}-3$ \\
\hline \multicolumn{4}{|c|}{ Failure Time $=100$ years } \\
\hline $10^{-6}$ & $1.810^{-4}$ & $6.110^{-4}$ & $3.310^{-4}$ \\
\hline $5.510^{-8}$ & $2.910^{-4}$ & $7.710^{-4}$ & $4.310^{-4}$ \\
\hline $10^{-8}$ & $3.510^{-4}$ & $7.310^{-4}$ & $4.210^{-4}$ \\
\hline
\end{tabular}

\section{Carbon-14}

Analyses were also performed for $\mathrm{C}-14$ release rates as a function of liner lifetime. Due to the long half-life of C-14 (5730 years) compared to the failure times and the low diffusion coefficient of $\mathrm{C}-14$ in the activated concrete. The predicted releases were not sensitive to the failure time and the discussion on C-14 releases from an instantaneously failed liner remain essentially unchanged. The cumulative fractional release over 1000 years ranged from $6.0 \%$ for a 100 -year liner lifetime to $6.1 \%$ for instantaneous liner failure.

\section{Effect of Partial Failure}

Modeling of partial failure due to pitting was not performed. The pitting modeling suggested breakthrough would not occur prior to 35 years for all conditions considered. For the conditions likely to be found at Maine Yankee, it is more likely that through pitting would not occur for much longer periods. Therefore, it is unlikely that breach due to pitting will occur prior to the minimum lifetime assumed for the analysis, 25 years. However, if the pitting caused partial failure of the liner prior to the assumed total failure time, as a first approximation, the amount released from a partially failed liner should be directly proportional to the release from a totally failed liner at that time scaled by the fraction of the area that is failed. The fraction of failed area should be small due to the conservative nature of the selected failure times.

\section{Conclusions}

Modeling has been performed to examine the potential releases from activated concrete in the ICI sump at Maine Yankee. Two radionuclides were considered in the assessment, H-3 and C14. Tritium was selected because it constitutes over $60 \%$ of the inventory and had the highest 
dose impact of all contaminants in the concrete. Carbon-14 was selected because of its long-half life and high dose impact. A key parameter in the assessment is the lifetime of the 3/8-inch carbon steel liner. Estimates of general and pitting corrosion were performed for a wide range of conditions and the data indicated that under expected conditions the liner should last several hundred years. Under the most aggressive conditions the lifetime was predicted to be around 50 years for either general or pitting corrosion. To address a combination of corrosion mechanisms, a minimum lifetime of 25 years was selected for analysis of releases. Lifetimes of 0,50 , and 100 years were also selected. The release modelling showed that if the liner failed immediately, H-3 releases could be as high as $37 \%$ in one year. If the liner lasted only 25 years, the maximum release was limited to $3.1 \%$ of the inventory with a maximum cumulative release of less than $8 \%$. Finite difference modeling of the release of $\mathrm{C}-14$ showed a release of $5 \%$ in the first year, this was due to the numerical treatment of the discontinuity at the interface of the activated concrete $\left(\mathrm{D}=10^{-12} \mathrm{~cm}^{2} / \mathrm{s}\right)$ and the porous medium $\left(\mathrm{D}=10^{-6} \mathrm{~cm}^{2} / \mathrm{s}\right)$. The cumulative release over 1000 years is predicted to be $6.1 \%$. Due to the long half-life of C-14, the release is essentially independent of liner failure time.

\section{References}

[Gerhold, 1981]

Gerhold, W.F., E. Escalante, and B.T. Sanderson, "The Corrosion Behavior of Selected Stainless Steels in Soil Environments," NBSIR 81-2228, National Bureau of Standards, 1981.

[Logan, 1939]

Logan, K.H., "Engineering Significance of National Bureau of Standards Soil-Corrosion Data," Journal of Research of the National Bureau of Standards, Vol. 22, January 1939.

[Marsh, 1985]

Marsh, G.P., Bland, I.D., Desport, J.A., Naish, C., Westcott, C., and Taylor, K.J., "Corrosion Assessment of metal overpacks for radioactive waste disposal," Scientific Basis for Nuclear Waste Management IX, Materials Research Society, Pittsburgh, PA, 421 (1985).

[Mughabghab, 1989]

Mughabghab, S.F., and T.M. Sullivan, "Evaluation of the Pitting Corrosion of Carbon Steels and other Ferrous Metals in Soil Systems," Waste Management, V. 9, pp 239 $251,1989$.

[Pescatore, 1991]

Pescatore, C."Leach Rate Expressions for Performance Assessment of Solidified, LowLevel Radioactive Waste," Journal of Nuclear and Chemical Waste Management, 1991.

[Romanoff, 1957]

Romanoff, M., "Underground Corrosion," National Bureau of Standards Circular 579, 1957. 
[Sullivan, 1988]

Sullivan, T.M., C.R. Kempf, C.J. Suen, and S.F. Mughabghab, "Low-Level Radioactive Waste Source Term Model Development and Testing," NUREG/CR-5204, BNLNUREG-52160, Brookhaven National Laboratory, 1988.

[Sullivan, 1993]

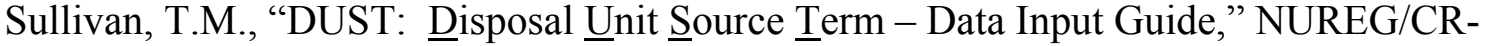
6041, BNL-NUREG-52375, Brookhaven National Laboratory, 1993. 